\title{
Çarșamba Ovasının Buğday Bitkisi Altındaki Topraklarının Bazı Fiziksel ve Kimyasal Özelliklerinin İncelenmesi
}

\author{
Nalan KARS' İmanverdi EKBERLi 12 * *
}

'T.C. Tarım ve Orman Bakanlığı, Karadeniz Tarımsal Araștırma Enstitüsü Müdürlüğü, Samsun

${ }^{2}$ Ondokuz Mayıs Üniversitesi, Ziraat Fakültesi Toprak Bilimi ve Bitki Besleme Bölümü, Samsun

\begin{abstract}
*Sorumlu yazar e-mail (Corresponding author e-mail): iman@omu.edu.tr
Geliș tarihi (Received) : 31.10.2018

Kabul tarihi (Accepted): 17.01.2019

DOI : $10.21657 /$ topraksu.544657
\end{abstract}

\section{Öz}

Bu çalıșmada, Çarșamba Ovasının buğday bitkisi yetiștirilen tarım topraklarının bazı fiziksel, kimyasal özelliklerinin belirlenmesi ve dağılımı araștırımıștır. Bu amaçla, Samsun ilinde yer alan Çarșamba Ovasının 20 köyünde çiftçiler tarafından tarım yapılan arazilerden toprak örnekleri alınmıștır. Araștırma 2013-2014 yılları arasında aynı arazilerde yürütülmüștür. Araștırmanın amacı doğrultusunda, toprakların bazı fiziksel (tekstür, tarla kapasitesi, solma noktası, hacim ağırlığı) ve kimyasal (organik madde, toprak reaksiyonu, elektriksel iletkenlik, kireç içeriği, toplam azot, değișebilir katyonlar, yarayıșlı fosfor, katyon değișim kapasitesi, alınabilir Fe, Cu, Zn, Mn) özellikleri belirlenmiștir. Araștırma sonucuna göre, buğday bitkisi yetiștirilen toprakların çoğunluğu killi tın bünyeye sahip, hacim ağırlığı değerleri orta (\%65'i), \%85'inin tarla kapasitesi değerleri \%20-\%40 arasında belirlenmiștir. Toprakların büyük bir çoğunluğu (\%72.5'i) hafif alkalin reaksiyonlu, tuzsuz, değișik miktarlarda kireç içermekte olup, organik madde miktarı orta düzeyde belirlenmiștir. Toprakların azot miktarı düșük (\%57.5'i), fosfor miktarı az (\%30'i); orta (\%35'i); yüksek (\%35'i), potasyum düzeyi orta (\%57.5'i), katyon değișim kapasitesi ise orta (\%17.5'i), yüksek (\%47.5'i) ve çok yüksek (\%35'i) olarak saptanmıștır. Toprakların demir miktarı (\%62.5'i) orta, bakır miktarı (\%100'ü) çok yüksek, mangan miktarı çok düșük (\%50'si) ve düșük (\%50'si), çinko miktarı ise çok düșük (\%80'ni) düzeyde bulunmuștur.

Anahtar Kelimeler: Buğday bitkisi, Çarșamba ovası, fiziksel ve kimyasal özellikler, frekans dağılımı

\section{Investigation of Some Physical and Chemical Properties of Soil Under Wheat Plant of Çarșamba Plain}

\begin{abstract}
In this study, determination and distribution of some physical and chemical properties of agricultural soils wheat plant were grown in Çarșamba Plain were investigated. For this purpose, soil samples were taken from agricultural land cultivated by farmers in twenty villages of Çarșamba Plain in Samsun. The study was carried out between 2013-2014 in the same land. In accordance with this purpose, some physical (texture, field capacity, wilting point, bulk density) and chemical properties of soils (organic matter, soil reaction, electrical conductivity, lime content, total nitrogen, exchangeable cations, available phosphorus, cation exchange capacity, available $\mathrm{Fe}, \mathrm{Cu}, \mathrm{Zn}$ and $\mathrm{Mn}$ ) were determined. According to results of research, the majority of the soils wheat crops were grown were found to have clayey loam textured, medium bulk density values (65\%) and field capacity values of $85 \%$ were found as $20 \%-40 \%$. The great majority of the soils $(72.5 \%)$ had slightly alkaline
\end{abstract}


reaction and different amounts of lime contents and amounts of organic matter in the soils were determined to be moderate and soils were without salt. The amounts of nitrogen in the soils were low (57.5\%) and potassium were medium (57.5\%). 30\% of phosphorus was defined as low, 35\% as medium and $35 \%$ as high. $17.5 \%$ of cation exchange capacity was defined as medium, $47.5 \%$ as high and 35\% as very high (35\%). Amount of iron in the soils were (62.5\%) medium, amount of copper (100\%) was very high, half of manganese content was very low (50\%) and the other half was low (50\%) and amount of zinc was very low (80\%).

Key words: Çarșamba plain, frequency distribution, physical and chemical properties, wheat plants.

\section{Giriș}

Çeșitli yöntemler kullanılarak toprak verimliliğinin artırıması ve tahmin edilmesi güncel ve araștırma önceliği olan konulardan biridir. Toprak verimliliğinin artırıması ve korunması, toprak özelliklerinin değișiminin optimum düzeyde tutulması ile ilișkilidir. Sanayileșme ve çarpık kentleșme sonucu gittikçe daralan ve hızla kirlenen tarım topraklarımızın sürdürülebilirliği için toprakların fiziksel, kimyasal ve biyolojik özelliklerinin iyi bir șekilde bilinmesi ve bu özelliklere göre gerekli tedbirlerin alınması bir zorunluluk haline gelmiștir. Toprakların fiziksel ve kimyasal özellikleri ve değișimi toprak olușum süreçlerine, verimliliğe ve bitki gelișimine önemli düzeyde etki yapmaktadır.

Dünyada ve ülkemizde hem ekiliș alanı hem de üretimi en fazla olan tahıl bitkisi buğdaydır (Triticum aestivum L.). Buğday, dünya nüfusunun yaklașık \%35'inin temel besin kaynağı olup, tüm besinlerden alınan kalorinin \%20 'sini sağlamaktadır (Kün, 1996). Dünya buğday üretimi 751.5 milyon ton, ekim alanı 2.22.10 ha, verimi ise $338 \mathrm{~kg} \mathrm{da}{ }^{-1} \mathrm{~d}$ ir (Anonymous, 2016). Ülkemizde buğday ekim alanı 7671945 ha, üretimi 20.6 milyon ton ve verimi ise 269 $\mathrm{kg} \mathrm{da}^{-1}$ olarak bitkisel üretimde çok önemli bir yer tutmaktadır (Anonim, 2016). Karadeniz bölgesinde en önemli tarımsal potansiyele sahip olan Çarșamba Ovası'nda, buğday bitkisinin ekiliș alanı 1200 ha, üretimi 359.5 ton, verimi 300 kg $d a^{-1} d ı r$.

Araștırmacılar tarafından çeșitli bitkiler yetiștirilen tarım topraklarının verimlilik düzeyini belirlemek ve artırmak amacıyla yürütülen çalıșmalarda, toprakların fiziksel ve kimyasal özellikleri incelenmiș, uygun sınıflandırmalar yapılmıștır (Ekberli vd., 2005; Ekberli ve Kerimova, 2005; Heuscher vd., 2005; Xu vd., 2005; Ekberli ve Kerimova, 2008; Martines vd., 2008; Parlak vd., 2008; Dengiz vd., 2009; Kendal vd., 2011; Wilson vd., 2013; Hossain vd., 2015; Ekberli ve Dengiz, 2016; Gülser vd., 2016; Özyazıcı vd., 2016; Dengiz ve Ekberli, 2017; Ekberli ve Dengiz, 2017; Martin vd., 2017). Günümüzde tarım alanlarında yapılmakta olan çeșitli toprak ișlemleri de topraklarım fiziksel ve kimyasal özelliklerine önemli düzeyde etki yapmaktadır (Gülser vd., 2010; Dengiz ve Gülser, 2014). Turan vd. (2010) tarafindan, Bursa ili alüviyal büyük toprak grubu tarım topaklarının verimlilik durumlarının ortaya konması ve potansiyel beslenme sorunlarını saptamak amacıyla 30 adet toprak örneği alınarak toprakların bazı fiziksel ve kimyasal özellikleri belirlenmiștir. Özyazıcı vd. (2016), Orta ve Doğu Karadeniz bölgesine ait 3400 adet toprak örneğinde yürüttükleri bir çalıșmada; büyük çoğunluğunun (\%75.30'u) tınlı topraklar olduğunu, $\mathrm{pH}$ değerlerinin çok değișkenlik (<4.5-8.5 arasında) gösterdiğini, toprakların organik madde içeriğinin büyük bir kısmının orta-iyi-yüksek düzeyde, tuzsuz ve \%61.15'i az kireçli olduğunu belirlemișlerdir. Ayrıca, araștırmada toprakların \%58.83'ünde fosfor noksanlığı görüldüğü, toprakların \%42.68'inde ekstrakte edilebilir potasyumun yeterli olduğu bildirilmiștir. Çimrin ve Boysan (2006) tarafından yapılan bir araștırmada, Van ili çevresi buğday yetiștirilen tarım topraklarının verimlilik durumu belirlenmiștir. Parlak vd. (2008) tarafından, Çanakkale'nin Eceabat ilçesinde çeșitli bitki (buğday, domates, ayçiçeği, zeytin) altındaki tarım topraklarının verimlilik durumlarının incelenmesine ait bir araștırmada, toprakların bazı fiziksel ve kimyasal özellikleri belirlenmiștir. Zengin ve Șeker (2003), Konya'nın Beyșehir ilıçesi tarım topraklarının (buğday, arpa, mercimek) verimlilik durumlarını belirlemek amacıla yaptıkları bir araștırmada, 48 toprak örneğini incelemișlerdir. Araștırma sonucunda toprakların N, P, K, Fe, Cu, 
Mn ve $\mathrm{Zn}$ ortalama değerlerinin sırasıyla 104.73; $24.48 ; 502.9 ; 15.62 ; 5.84 ; 2.74$ ve $2.62 \mathrm{mg} \mathrm{kg}^{-1}$ olduğunu bildirmișlerdir. Bursa İli Kahverengi Orman Büyük Toprak Grubu topraklarının verimlilik durumunu belirlemek amacıyla yapılan bir araștırmada da, araștırma alanını temsil edebilecek șekilde 28 adet toprak örneği alınmıș ve bu örneklerin bazı fiziksel ve kimyasal özellikleri belirlenmiștir (Tümsavaș ve Aksoy, 2009). Buğday bitkisi yetiștirilen toprakların verimlilik düzeyinin artııımasında çeșitli tarımsal ișlemlerin belirlenmesi ve uygulanması da, genel olarak toprakların fiziksel, kimyasal özelliklerinin belirlenmesiyle ilișkili olmaktadır (Cantero-Martinez vd., 2007; Gürsoy vd., 2010; Machado vd., 2007; Özdemir vd., 2014).

Bu çalıșmanın amacı, Çarșamba Ovası́nın buğday bitkisi altındaki tarım topraklarının bazı fiziksel ve kimyasal özelliklerinin belirlenmesi ve dağııımının saptanmasıdır.

\section{MATERYAL VE YÖNTEM}

Samsun ili Çarșamba Ovası, Türkiye'nin Samsun ilinin doğusunda Canik dağları ile Karadeniz arasında Yeșilırmak'ın olușturduğu delta ovasıdır. Ova 0-50 m kotları arasında, 103766 hektarlık alanı kapsamaktadır. Çarșamba Ovası doğu-batı istikametinde 65 km, güneykuzey istikametinde ise $35 \mathrm{~km}$ uzunluğa sahiptir. Ova taban arazilerinin genel eğimleri güneykuzey istikametinde olup ortalama \%0.1'dir. Bu eğim, deniz kenarına yaklaștıkça \%0-0.02'ye kadar düșmektedir. Yamaç arazilerde ise eğim, \%2-40 arasında değișmektedir (Anonim, 1984; Anonim, 2012). Ova, bitki örtüsü yönünden çok zengin olup, 58.921 hektar tarım arazisine sahiptir. Ovada buğday bitkisi 1.700 ha, dane misır bitkisi 5.950 ha ve soya bitkisi ise 560 ha alanda yetiștirilmektedir. Ova toprakları alüvyal ve kısmen de kolüvyal (kestane rengi topraklar, gri-kestane podzolik topraklar, kahverengi orman toprakları) karakterdedir. Ovada yıllık toplam yağıș miktarı 985.9 mm olup, yıllık sıcaklık ortalaması ise $15-17^{\circ} \mathrm{C}^{\prime} \mathrm{dir}$.

Araștırma 2013-2014 yıllarında Samsun ili Çarșamba Ovasını temsil eden 20 köyde, çiftçiler tarafından tarım yapılan arazilerden 0-20 cm derinlikten Jackson (1962) tarafından bildirildiği șekilde her yıl için 20 toprak örneği alınarak gerçekleștirilmiștir. Toprak örneklerinin alındığı lokasyonlar Șekil 1'de gösterilmiștir.

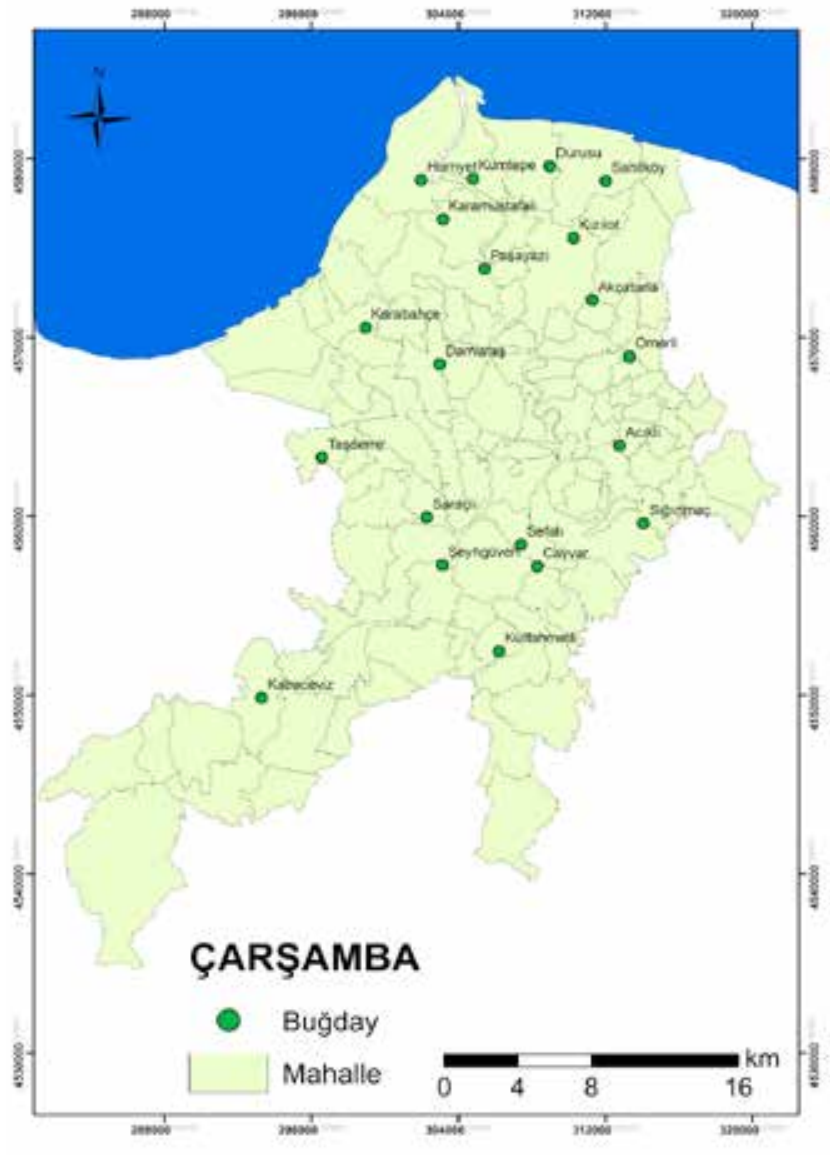

Șekil 1. Toprak örneklerinin alındığı lokasyonlar

Figure 1. Locations where soil samples are taken

Toprak tekstürü hidrometre yöntemiyle (Demiralay, 1993); toprak reaksiyonu (pH), 1:1 oranında hazırlanan toprak-su süspansiyonunda ve cam elektrotlu $\mathrm{pH}$ metre ile belirlenmiștir (Bayraklı, 1987). Elektriksel iletkenlik (EC), 1:1 oranında hazırlanan toprak-su süspansiyonunda elektriksel kondaktivite aleti ile (Richards, 1954); kireç $\left(\mathrm{CaCO}_{3}\right)$ Scheibler kalsimetresiyle volümetrik (Kacar, 1994); organik madde Walkley-Black yaș yakma (Kacar, 1994); azot içeriği ise Kjeldahl yaș yakmayöntemine göre (Kacar, 1994) belirlenmiștir. Yarayıșlı P içeriği, mavi renk yöntemine göre (OIsen vd, 1954); değișebilir K ve Na, toprak örneğinin 1 $\mathrm{N}$ amonyum asetat $(\mathrm{pH}=7.0)$ çözeltisi ile ekstrakte edilmesiyle, Ca ve Mg 0.01 M EDTA ile titre edilerek (Sağlam, 1997); katyon değișim kapasitesi, Bower yöntemine göre (U.S. Salinity Lab. Staff., 1954); alınabilir Fe, Cu, Mn ve Zn içerikleri (0.005 M DTPA $+0.01 \mathrm{M} \mathrm{CaCl} 2+0.1 \mathrm{M} \mathrm{TEA}, \mathrm{pH}=7.3$ ) ise Lindsay ve Norvell (1969) tarafindan bildirildiği șekli ile belirlenmiștir. Tarla kapasitesi (TK) ve solma noktası (SN) değeri, basınçlı tabla aletinde 1/3 atm (TK) ve 15 atm (SN) basınç altında toprak örneklerinin 
hidrolik denge durumuna gelmesinden sonra, ağırlık esasına göre (Black, 1965); bitkiye yarayıșlı su miktarı (BYS), tarla kapasitesi ve solma noktası arasındaki farktan belirlenmiștir.

\section{İstatistikler Analizler}

Toprak analizi sonuçlarına ait tanımlayıcı istatistikler SPSS 17.0 paket programında

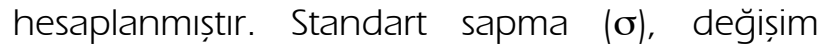
veya varyasyon katsayısı (VK) sırasıyla așağıdaki ifadelerle belirlenmiștir:

$$
\begin{gathered}
\sigma=\sqrt{\frac{1}{n} \sum_{i=1}^{n}\left(X_{i}-\bar{X}\right)^{2}} \\
V K=\sqrt{\frac{1}{n} \sum_{i=1}^{n} \frac{\left(X_{i}-\bar{X}\right)^{2}}{\bar{X}}}
\end{gathered}
$$

(burada, Xi - ölçülen veya tahmin edilen değerler; $\bar{X}$ ölçülen veya tahmin edilen değerlerin ortalaması; n -ölçülen veya tahmin edilen değerlerin sayısıdır)

Genel olarak; standart sapmanın küçük olması ortalamadan sapmaların ve riskin az, büyük olması ise, ortalamadan sapmaların ve riskin çok olduğunun göstergesidir. Varyasyon veya değișim katsayıları karșılaștıııldığında, değișim katsayısı küçük olan verilerde dağııımın aritmetik ortalama etrafında daha yoğun dağıldığı anlașilır.

\section{BULGULAR VE TARTIȘMA}

Buğday Bitkisi Yetiștirilen Toprakların Fiziksel Özelliklerinin Dağılımı

Buğday bitkisi yetiștirilen toprakların bazı fiziksel özelliklerine ait tanımlayıcı istatistikler Çizelge 1'de verilmiștir.
Çizelge l'den görüldüğü gibi, buğday yetiștirilen toprakların kil miktarı \%18.19-52.98 arasında değișmekte olup, ortalama değeri ise \%31.01'dir. Standart sapma 9.26; varyasyon katsayısı \%29.86; çarpıklık katsayısı ise 0.599 olarak saptanmıștır. Toprakların silt miktarı \%26.21-57.02 arasında değișmekte, ortalama değeri \%39.79'dur. Standart sapma, varyasyon katsayısı, çarpıklık katsayısı sırasıyla 8.28; 20.80; 0.257 'dir. Toprakların kum miktarı \%15.9547.62 arasında değișirken ortalaması \%29.19 olmuștur. İstatistiksel göstericiler sırasıyla 9.45; \%32.37; 0.607 olarak bulunmuștur. Buğday yetiștirilen topraklarının bünyesi killi tın, killi, tınlı ve siltli tın olarak saptanmıștır. Toprakların minumum hacim ağırlığı $1.09 \mathrm{~g} \mathrm{~cm}^{-3}$, maksimum hacim ağırlığı ise $1.54 \mathrm{~g} \mathrm{~cm}^{-3}$ olup, ortalama değer $1.33 \mathrm{~g} \mathrm{~cm}^{-3}$ olarak bulunmuștur. Standart sapması 0.14; varyasyon katsayısı \%11.02; çarpıklık katsayısı ise $-0.114^{\prime}$ tür. Toprakların tarla kapasitesi değeri \%17.18-40.93 arasında değișmekte, ortalama \%29.18'dir. Standart sapma, varyasyon katsayısı, çarpıklık sırasıyla 6.92; \%23.71; -0.011 olarak belirlenmiștir. Buğday topraklarında solma noktası \%7.9224.31 arasında değișmekte, ortalama \%14.32, standart sapma 4.84, varyasyon katsayısı \%33.79 ve çarpıklık katsayısı 0.496 olarak belirlenmiștir. Buğday topraklarında bitkiye yarayıșlı su miktarı \%4.09-32.28 arasında değișmekte, ortalaması ise \% 14.85'dir. Standart sapma, varyasyon katsayısı, skewness katsayısı sırasıyla 5.46; \%36.76; 0.787 olarak bulunmuștur. Görüldüğü gibi, tanımlayıcı istatistiksel göstericiler geçerlilik sınırları dahilinde olmaktadır.

Buğday bitkisi yetiștirilen toprakların, hacim ağırlığı, kil ve tarla kapasitesi değerlerine ait frekans dağılımları Șekil Z'de verilmiștir.

Çizelge 1. Buğday bitkisi yetiștirilen toprakların bazı fiziksel özelliklerine ait bazı tanımlayııı istatistikler ( $n=40)$

Table 1. Some descriptive statistics of some physical properties of soils grown in wheat plants ( $n=40$ )

\begin{tabular}{ccccccc}
\hline Özellikler & Min. & Mak. & Ort. & $\sigma$ & VK, \% & Çarpıklık \\
\hline Kil, \% & 18.19 & 52.98 & 31.01 & 9.26 & 29.86 & 0.599 \\
Silt, \% & 26.21 & 57.02 & 39.79 & 8.28 & 20.80 & 0.257 \\
Kum, \% & 15.95 & 47.62 & 29.19 & 9.45 & 32.37 & 0.607 \\
Db, g cm & 1.09 & 1.54 & 1.33 & 0.13 & 9.77 & -0.114 \\
TK, \% & 17.18 & 40.93 & 29.18 & 6.92 & 23.71 & -0.011 \\
SN, \% & 7.92 & 24.31 & 14.32 & 4.84 & 33.79 & 0.496 \\
BYS, \% & 4.09 & 32.28 & 14.85 & 5.46 & 36.76 & 0.787 \\
\hline
\end{tabular}

Db: Hacim ağırlığı; TK: Tarla kapasitesi; SN: Solma noktası; BYS: Bitkiye yarayıșıı su; o: Standart sapma; VK: Varyasyon katsayısı. 


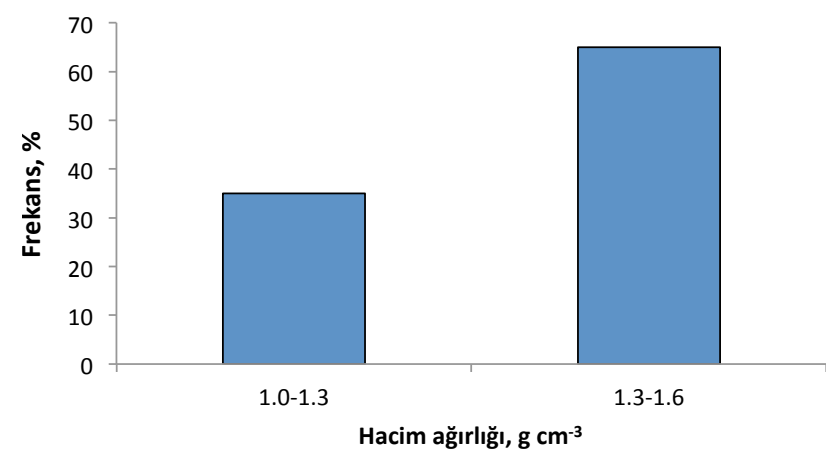

Șekil 2. Buğday bitkisi yetiștirilen toprakların hacim ağırlığı dağılımı (n=40)

Figure 2. Volume weight distribution of soils grown in wheat plants $(n=40)$

Șekil 2'den görüldüğü gibi, buğday yetiștirilen toprakların hacim ağırlığı değerlerinin \%35'i düșük (1.0-1.3 $\left.\mathrm{g} \mathrm{cm}^{-3}\right)$ ve \%65'i ise orta (1.3-1.6 $\mathrm{g} \mathrm{cm}^{-3}$ ) olarak belirlenmiștir. Wilson vd (2013) yaptıkları çalıșmada, Mollisol topraklarda toprak havalanmasının yetersiz olması nedeniyle, hacim ağırlığının $1.4 \mathrm{~g} \mathrm{~cm}^{-3}$ değerinde, buğday bitkisinin büyümesinin sınırlandığını bildirmișlerdir.

Buğday bitkisi yetiștirilen toprakların çoğunluğu killi tın bünyeye sahip olup, genel olarak topraklarda kil miktarı fazla olmamaktadır (Șekil 3).

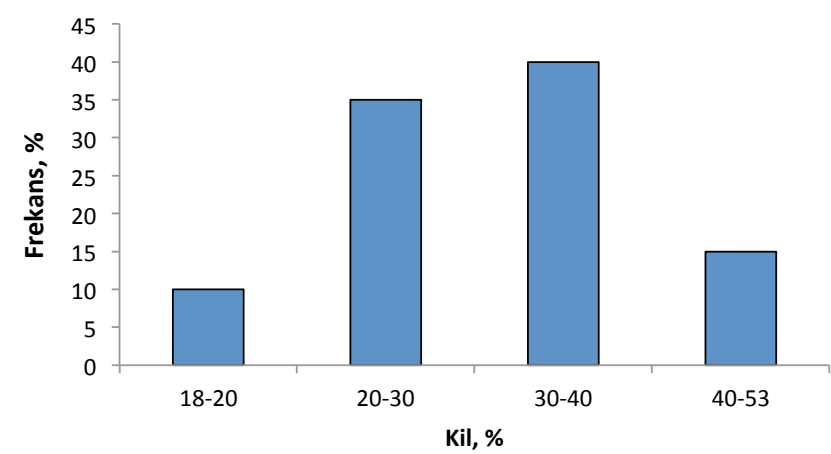

Șekil 3. Buğday bitkisi yetiștirilen topraklarda kil miktarının dağılımı (n=40)

Figure 3. Distribution of the amount of clay in soils grown in wheat plants $(n=40)$

En düșük kil miktarı \%18 ile \%20, en yüksek kil miktarı ise \%40 ile \%53 arasında değișmekte olup, araștırma topraklarının sırasıyla \%10 ve \%15'ni olușturmaktadır. Araștırmacılar (Çolakoğlu, 1985; Fageria vd., 1991; Bașar, 2001) tarafından, kumlutın'dan killi-tın bünyeye değișen farklı topraklarda buğday bitkisinin yetiștirilebileceği bildirilmiștir.

Șekil 4'de görüldüğü gibi; buğday yetiștirilen toprakların \%5'inde tarla kapasitesi \%15 ile \%20; $\% 85^{\prime}$ inde $\% 20$ ile \%40; \%10'unda ise \%40 ile \%45 arasında değișmektedir.

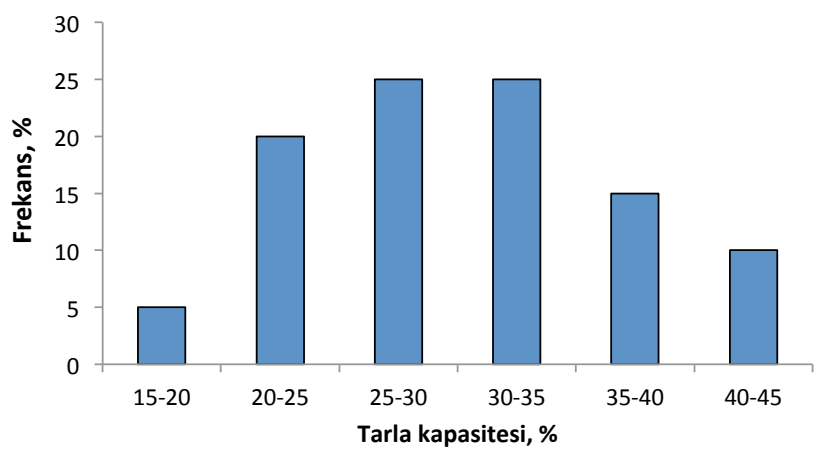

Șekil 4. Bugday bitkisi yetiștirilen topraklarda tarla kapasitesi dağılımı $(n=40)$

Figure 4. Field capacity distribution in soils grown in wheat plants $(n=40)$

Genel olarak, killi tın ve killi topraklarda tarla kapasitesinin \%44; tınlı ve siltli topraklarda ise \%36 olduğu pek çok araștırmacı tarafından bildirilmiștir (Campbell, 1985; Kauriçev, 1989, Brohi vd., 1997). Șeker ve Karakaplan (1999), Konya Ovası́nda toprak özellikleri ile kırıma değerleri arasındaki ilișkilerin belirlenmesine ait bir çalıșmada, toprakların tarla kapasitelerinin \% 14.91 ile \%37.08 arasında değiștiğini belirlemișlerdir.

\section{Buğday Bitkisi Yetiștirilen Toprakların Kimyasal Özelliklerinin Dağılımı}

Buğday bitkisi yetiștirilen toprakların bazı kimyasal özelliklerine ait tanımlayıcı istatistikler Çizelge 2'de verilmiștir.

Çizelge 2'den görüldüğü gibi, buğday yetiștirilen topraklar nötr ve hafif alkali reaksiyona sahip olup, ortalama $\mathrm{pH}$ değeri 7.53'tür. Standart sapma, varyasyon katsayısı, çarpıklık sırasıyla 0.37; \%4.91; -1.232 olarak saptanmıștır. Toprakların ortalama EC miktarı 0.48 dS $\mathrm{m}^{-1}$ olup topraklar genellikle tuzsuz sınıfında yer almaktadır. Standart sapma 0.13; varyasyon katsayısı \%27.08; çarpıklık katsayısı ise -1.304 'tür. Buğday yetiștirilen topraklar kireç içeriği bakımından kireçsiz, orta kireçli ve kireçli arasında değișmekte olup, ortalama kireç miktarı \%5.23'tür. İstatistiksel parametreler sırasıyla 3.91; \%74.76 ve 0.445 olarak belirlenmiștir. Toprakların organik madde kapsamı çoğunlukla orta düzeyde olup, ortalama \%2.40'dır. Standart sapma, varyasyon katsayısı, çarpıklık ölçütü sırasıyla 1.08; \%45.00; 0.589 olarak saptanmıștır. Toprakların azot içeriği çoğunlukla düșük olup, ortalama azot miktarı \%0.16'dır. Standart sapma 0.05; varyasyon katsayısı \%31.25; çarpıklık katsayısı ise 0.625 olarak belirlenmiștir. Topraklar fosfor bakmından az, orta ve çok yüksek arasında değișmekte 
Çizelge 2. Buğday bitkisi yetiștirilen toprakların bazı kimyasal özelliklerine ait bazı tanımlayıcı istatistikler (n=40)

Table 2. Some descriptive statistics of some chemical properties of soils grown in wheat plants

\begin{tabular}{ccccccc}
\hline Özellikler & Min. & Mak. & Ortalama & $\sigma$ & VK, \% & Carpılık \\
\hline $\mathrm{pH},(1: 1)$ & 6.57 & 7.97 & 7.53 & 0.37 & 4.91 & -1.232 \\
$\mathrm{EC}, \mathrm{dS} \mathrm{m}^{-1}(1: 1)$ & 0.31 & 0.91 & 0.48 & 0.13 & 27.08 & 1.304 \\
$\mathrm{CaCO}_{3^{\prime}} \%$ & 0.41 & 13,86 & 5.23 & 3.91 & 74.76 & 0.445 \\
$\mathrm{OM}, \%$ & 0.60 & 4.73 & 2.40 & 1.08 & 45.00 & 0.589 \\
$\mathrm{~N}, \%$ & 0.07 & 0.27 & 0.16 & 0.05 & 31.25 & 0.623 \\
$\mathrm{P}, \mathrm{ppm}$ & 1.67 & 119.45 & 22.97 & 33.34 & 145.14 & 2.122 \\
$\mathrm{~K}, \mathrm{cmol} \mathrm{kg}^{-1}$ & 0.21 & 2.77 & 0.69 & 0.61 & 88.40 & 2.316 \\
$\mathrm{Ca}+\mathrm{Mg}, \mathrm{cmol}$ & 17.99 & 62.38 & 32.88 & 10.67 & 32.45 & 0.944 \\
$\mathrm{~kg}$ & & & & & & \\
$\mathrm{Na}, \mathrm{cmol} \mathrm{kg-1}$ & 0.27 & 2.41 & 1.16 & 0.79 & 68.10 & 0.229 \\
$\mathrm{KDK}, \mathrm{cmol} \mathrm{kg-1}$ & 4.06 & 65.00 & 33.33 & 12.26 & 36.78 & 0.328 \\
$\mathrm{Fe}, \mathrm{ppm}$ & 11.66 & 85.88 & 31.21 & 20.65 & 66.16 & 1.609 \\
$\mathrm{Mn}, \mathrm{ppm}$ & 4.95 & 29.92 & 10.75 & 6.21 & 57.76 & 2.190 \\
$\mathrm{Cu}, \mathrm{ppm}$ & 2.13 & 11.18 & 5.21 & 2.20 & 42.22 & 0.960 \\
$\mathrm{Zn}, \mathrm{ppm}$ & 0.36 & 6.95 & 1.40 & 1.62 & 115.71 & 2.215 \\
\hline
\end{tabular}

pH: Toprak reaksiyonu; EC: Elektriksel iletkenlik; CaCO3: Kireç; OM: Organik madde; N: Azot; P: Fosfor; K: Potasyum; Ca+Mg: Kalsiyum+Magnezyum; Na: Sodyum; KDK: Katyon değișim kapasitesi; Fe: Demir; Mn: Mangan; Cu: Bakır; Zn: Çinko.

olup, ortalama fosfor miktarı 22.97 ppm'dir. Standart sapma, varyasyon katsayısı, çarpıklık katsayısı sırasıyla 33.34; \%145.14; 2.122 olarak bulunmuștur. Toprakların potasyum kapsamı çoğunlukla orta ve yüksek düzey arasında olup, ortalama potasyum miktarı $0.69 \mathrm{cmol}$ $\mathrm{kg}^{-1}$ dır.Istatistiksel parametreler sırasıyla 0.61 ; \%88.40; 2.316 olarak saptanmıștır. Topraklarda $\mathrm{Ca}+\mathrm{Mg}$ miktarı $17.99-62.38 \mathrm{cmol} \mathrm{kg}^{-1}$ arasında değișmekte olup, ortalama değer $32.88 \mathrm{cmol}$ $\mathrm{kg}^{-1}$, istatistiksel göstergeler ise sırasıyla 10.67; \%32.45; 0.944 olmuștur. Toprakların sodyum miktarı en düșük $0.27 \mathrm{cmolkg}^{-1}$, en yüksek ise $2.41 \mathrm{cmol} \mathrm{kg}^{-1}$ dır. Ortalama sodyum miktarı $1.16 \mathrm{cmol} \mathrm{\textrm {kg } ^ { - 1 }}$ olup, toprakların sodyum kapsamı çoğunlukla orta ve yüksek seviyede olmaktadır. Standart sapma 0.79; varyasyon katsayısı \%68.10; çarpıklık katsayısı ise 0.229 olarak belirlenmiștir. Topraklardaki KDK seviyesi genellikle yüksek ve çok yüksek olup, ortalama KDK değeri $33.33 \mathrm{cmol} \mathrm{kg}^{-1}$ 'dır. Standart sapma, varyasyon katsayısı, çarpıkık katsayısı sırasıyla 12.26; \%36.78; 0.328 olarak saptanmıștır. Toprakların demir kapsamı genellikle yüksek düzeyde olup, ortalama demir miktarı 31.21 ppm'dir. İstatistiksel parametreler sırasıyla 20.65; \%66.16; 1.609 olarak bulunmuștur. Toprakların mangan kapsamları çoğunlukla düșük olup, ortalama mangan değeri 10.75 ppm'dir. Standart sapma, varyasyon katsayısı, çarpıklık katsayısı sırasıyla 6.21; \%57.76; 2.190 olarak belirlenmiștir. Toprakların bakır kapsamları çok yüksek düzeyde olup, ortalama bakır miktarı 5.21 ppm'dir. Standart sapma 2.20; varyasyon katsayısı \%42.22; çarpıklık katsayısı ise 0.960 bulunmuștur. Toprakların çinko kapsamları genellikle çok düșük olup, ortalama çinko miktarı 1.40 ppm'dir. İstatistiksel göstericiler sırasıyla 1.62; \%115.71; 2.215 olarak belirlenmiștir. Genel olarak, istatistiksel göstericiler geçerlilik sınırları dahilinde olmaktadır. Çiftçi koșullarında bazı tarımsal ișlemlerin (sulama, gübreleme, toprak ișleme vb.) düzenli yapılmaması, arazinin rölyefi, iklim șartları bazı parametrelerin $\left(\mathrm{CaCO}_{3}\right.$, $\mathrm{P}, \mathrm{K}, \mathrm{Na}, \mathrm{Fe}, \mathrm{Zn})$ homojen dağılmamasına, dolayısıyla istatistiksel göstericilerin güvenirlilik sınırları dıșında olmasına neden olabilir.

Buğday bitkisi yetiștirilen toprakların $\mathrm{pH}$, $E C, O M, N, P, K$ ve KDK miktarına ait frekans dağılımları Șekil 5-1 1'de gösterilmiștir. 


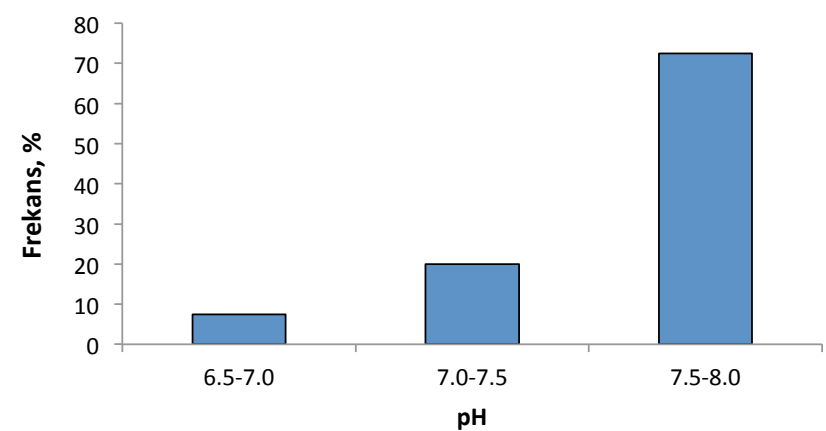

Șekil 5. Buğday bitkisi yetiștirilen toprakların pH değerlerinin dağılımı ( $\mathrm{n}=40)$

Figure 5. Distribution of $\mathrm{pH}$ values of soils grown in wheat plants $(n=40)$

Șekil 5'ten görüldüğü gibi, buğday bitkisi yetiștirilen araștırma topraklarının \%7.5'i çok hafif asit, \%20'si çok hafif alkalin, \%72.5'i ise hafif alkalin reaksiyonludur. Ülgen ve Yurtsever (1988) tarafından yapılan bir araștırmada, Türkiye'nin sekiz bölgesinden alınan toplam 64.591 toprak örneğinde, saturasyon çamurunun $\mathrm{pH}$ dağılımı \%0.9'u kuvvetli asit, \%4.5'i orta derecede asit, \%13.4'ü çok hafif asit, \%76.5'i nötr ve hafif alkalin, \%4.7'si ise orta ve kuvvetli alkalin olarak saptanmıștır.

Buğday bitkisi yetiștirilen araștırma topraklarının \%50'si 0.3-0.5 dS m-1 arasında, \%45'i 0.5-0.7 dS $\mathrm{m}^{-1}$ arasında ve \% $5^{\prime} \mathrm{i}$ 0.7-0.9 dS $\mathrm{m}^{-1}$ arasında belirlenmiștir (Șekil 6).

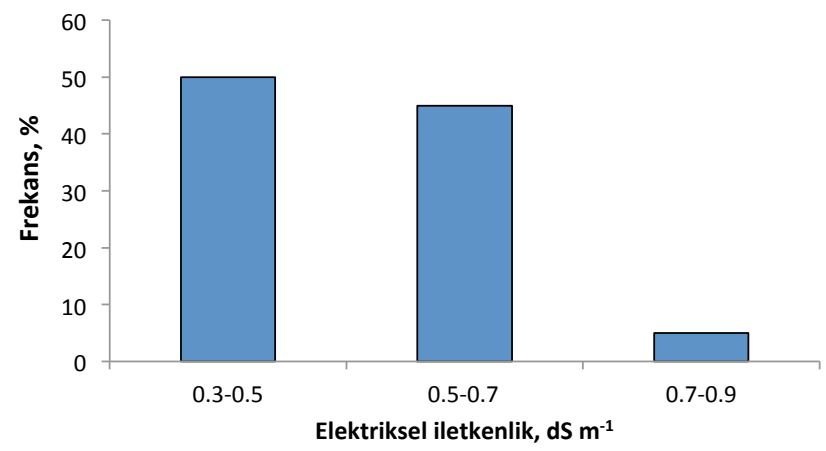

Șekil 6. Buğday bitkisi yetiștirilen topraklarda elektriksel iletkenlik değerlerinin dağıımı $(n=40)$

Figure 6. Distribution of electrical conductivity values in soils grown in wheat plants ( $n=40$ )

Araștırma toprakları tuz miktarlarının dağılımından görüldüğü gibi topraklarda tuz problemi yoktur. İç (2015), Çarșamba Ovası sol sahil topraklarında yorgunluk parametrelerini araștırdığı bir çalıșmada, alınan toprak örneklerinin EC değerlerinin $0.099 \mathrm{dS} \mathrm{m}^{-1}$ ile $1.338 \mathrm{dS} \mathrm{m}^{-1}$ arasında değișim gösterdiğini, ortalama EC değerinin $0.50 \mathrm{dS} \mathrm{m}^{-1}$ ve toprakların tuzsuz
(<2 dS m¹ ) olduğunu bildirmiștir. Bașar (2001) tarafından, Bursa ilinde buğday bitkisi yetiștirilen toprakıarın bazı verimlilik özelliklerinin belirlendiği bir çalıșmada, alınan 249 toprak örneğinin \%98.40'nın tuzsuz, \%1.60'nın ise hafif tuzlu olduğu bildirilmiștir.

Organik madde miktarı, buğday bitkisi yetiștirilen toprakların \%5'inde çok az $(<\% 1)$, $\% 47.5$ 'inde az (\%1-2), \%37.5'inde orta (\%2-3), $\% 5^{\prime}$ inde iyi (\%3-4) ve \%5'inde ise yüksek $(<\% 4)$ olarak belirlenmiștir (Șekil 7).

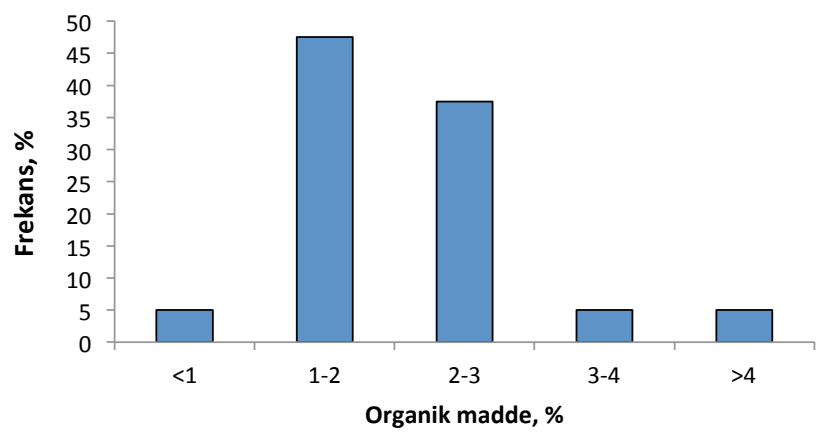

Șekil 7. Buğday bitkisi yetiștirilen topraklarda organik madde miktarının dağılımı ( $\mathrm{n}=40)$

Figure 7. Distribution of amount of organic matter in soils grown in wheat plants $(n=40)$

Ülgen ve Yurtsever (1988), Türkiye'nin sekiz bölgesinden alınan toplam 63.613 toprak örneğinde, organik madde miktarlarını toprakların \%19.2'sinde çok az, \%49.8'inde az, \%22.4'ünde orta, \%5.6'sında iyi ve \%3'ünde ise yüksek olarak belirlemișlerdir. Araștırmacılar, Karadeniz Bölgesi topraklarında organik madde miktarının göreceli olarak en yüksek olduğunu saptamıșlardır.

Șekil 8'den görüldüğü gibi, buğday bitkisi yetiștirilen araștırma topraklarının \%57.5'inde azot miktarı düșük (\%0.05-0.15), \%35'inde orta $(\% 0.15-0.25)$ ve $\% 7.5^{\prime}$ inde ise fazla $(\% 0.25-0.50)$ seviyede olmaktadır.

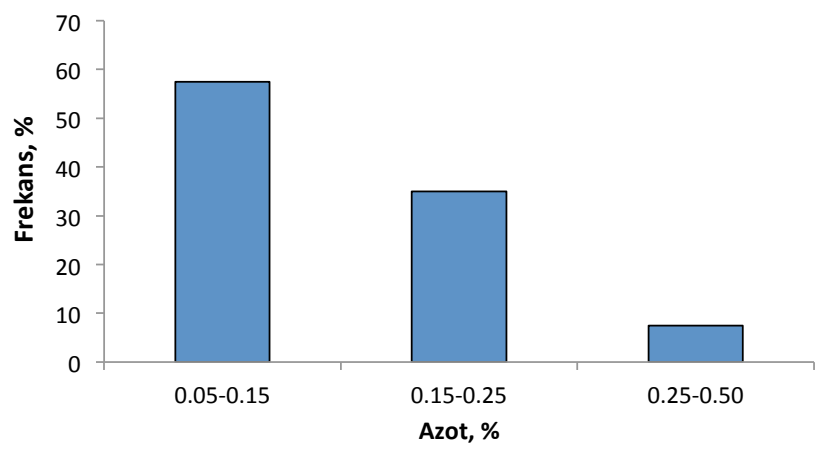

Șekil 8. Buğday bitkisi yetiștirilen topraklarda azot miktarının dağılımı (n=40)

Figure 8. Distribution of nitrogen content in soils grown in wheat plants $(n=40)$ 
Ortalama azot kapsamı ise \%0.16 olarak belirlenmiștir (Çizelge 2). Van ili ve çevresinde buğday tarımı yapılan alanları temsil edecek șekilde toplam 52 toprak örneği alınarak yürütülen bir araștırma sonucuna göre; toprakların \%11.5'inin azotça fakir, \%36.5'inin orta, \%46'sının iyive \%6'sının ise azot bakımından zengin durumda olduğu saptanmıștır (Çimrin ve Boysan, 2006).

Buğday bitkisi yetiștirilen araștırma alanında az (<6 ppm), orta (6-14 ppm), iyi (14-26 ppm), yüksek (26-38 ppm) ve çok yüksek (<38 ppm) fosfor miktarları, araștırma alanının sırasıyla \%30; \%35; \% 15; \%2.5 ve \%1 7.5 kısmını olușturmaktadır (Șekil 9).

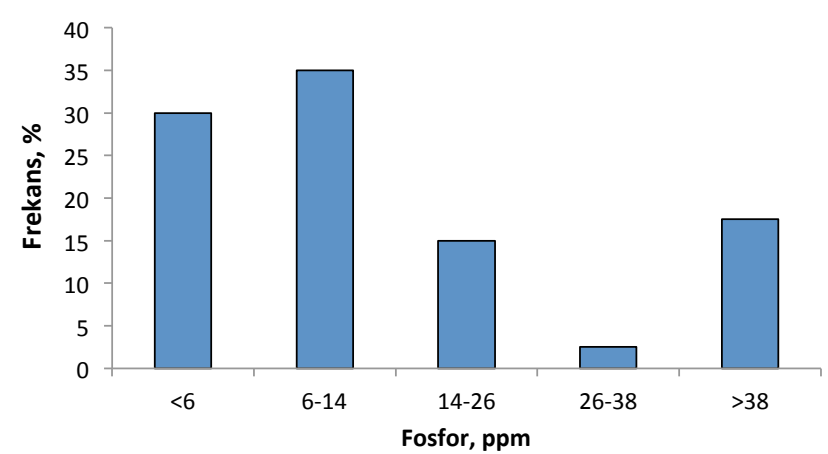

Șekil 9. Buğday bitkisi yetiștirilen topraklarda fosfor miktarının dağılımı (n=40)

Figure 9. Distribution of the amount of phosphorus in soils grown in wheat plants $(n=40)$

Görüldüğü gibi, araștırma toprakları fosfor kapsamı bakımından zengin değildir. Bursa ilinde buğday bitkisi yetiștirilen arazinin verimlilik dururumunu tespit etmek için yapılan bir çalıșmada, toprakların \%8.03'ünde çok düșük, \%59.04'ünde orta, \%32.93'ünde ise yüksek miktarda fosfor olduğu bildirilmiștir (Bașar, $2001)$.

Șekil 10'da görüldüğü gibi, buğday bitkisi yetiștirilen araștırma topraklarının \%15'inde potasyum miktarı düșük $(0.2-0.3 \mathrm{cmol} \mathrm{kg})$, $\% 57.5^{\prime}$ inde orta $\left(0.3-0.7 \mathrm{cmol} \mathrm{kg}^{-1}\right), \% 22.5^{\prime}$ inde yüksek $\left(0.7-2.0 \mathrm{cmol} \mathrm{kg}^{-1}\right), \% 5^{\prime}$ inde ise çok yüksek (>2 $\mathrm{cmol} \mathrm{kg}^{-1}$ ) olmaktadır.

Ortalama potasyum miktarı $0.69 \mathrm{cmol} \mathrm{kg}^{-1}$ olup (Çizelge 2), genel olarak araștırma topraklarında potasyum kapsamı orta düzeydedir. Tümsavaș (2002), tarafından yapılan bir araștırmada, kolüvyal grubu toprakların değișebilir potasyum içeriklerinin 0.20 ile $0.88 \mathrm{cmol} \mathrm{kg}^{-1}$ arasında

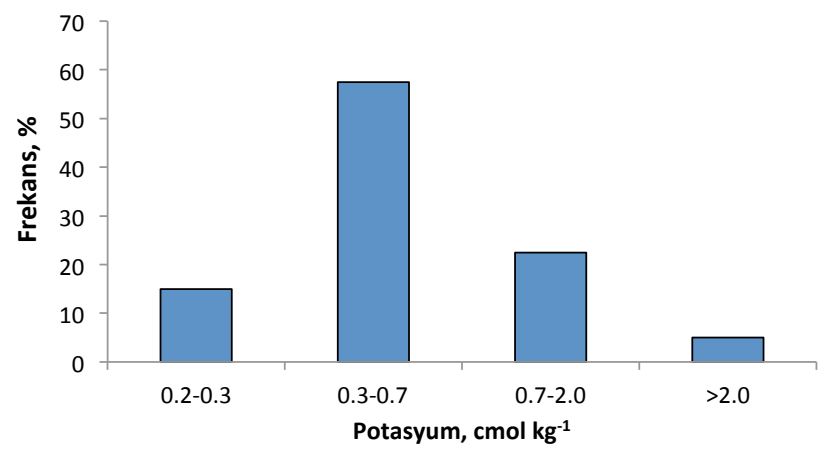

Șekil 10. Buğday bitkisi yetiștirilen topraklarda potasyum miktarının dağılımı $(\mathrm{n}=40)$

Figure 10. Distribution of the amount of potassium in soils grown in wheat plants $(n=40)$

değiștiği, toprakların \% 64'nün iyi, yüksek ve çok yüksek; \% 8'nin orta; \%28'nin ise düșük ve çok düșük düzeyde $\mathrm{K}$ içerdiği ve toprakların genellikle değișebilir potasyum içeriği bakımından iyi durumda olduğu belirtilmiștir.

Buğday bitkisiyetiștirilen araștırma topraklarında ortalama KDK değeri $33.33 \mathrm{cmol} \mathrm{kg}^{-1}$ 'dır (Çizelge 2). Orta $\left(12-25 \mathrm{cmol} \mathrm{kg}^{-1}\right)$, yüksek $(25-40 \mathrm{cmol}$ $\left.\mathrm{kg}^{-1}\right)$, çok yüksek (>40 cmol $\left.\mathrm{kg}^{-1}\right)$ düzeyde KDK miktarları, deneme alanının sırasıyla \%17.5; \%47.5 ve \%35.0'ni olușturmaktadır (Șekil 11 ).

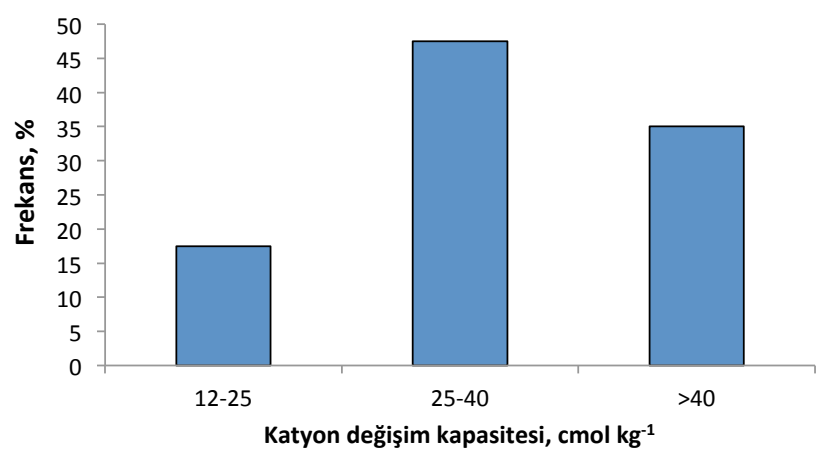

Șekil 11 . Buğday bitkisi yetiștirilen topraklarda katyon değișim kapasitesi değeri dağılımı (n=40)

Figure 11. Cation exchange capacity value distribution in soils grown in wheat plants $(n=40)$

Genel olarak, araștırma topraklarında KDK miktarı yüksek olmakta, toprak katmanlarının fiziksel-kimyasal bakımdan heterojenliğine önemli düzeyde etki yaptığı düșünülmektedir (Aydarov, 1985). Taban vd (1997), Orta Anadolu'da çeltik tarımı yapılan toprakların bazı fiziksel ve kimyasal Özelliklerini araștırdıkları bir çalıșmada, araștırma topraklarının katyon değișim kapasitesinin 21.30 $\mathrm{cmol} \mathrm{kg}$ ile $61.87 \mathrm{cmol} \mathrm{kg}^{-1}$ arasında değișim gösterdiğini ve toprakların \%90'ında katyon 
değișim kapasitesinin $25 \mathrm{cmol} \mathrm{kg-1'dan} \mathrm{yüksek,}$ \% $10^{\prime}$ unda ise $20-25 \mathrm{cmol} \mathrm{kg}^{-1}$ arasında olduğunu bildirmișlerdir.

\section{SONUCLAR}

Carșamba Ovası́nın buğday bitkisi altındaki tarım topraklarının bazı fiziksel ve kimyasal özellikleri belirlenmiș; bu özelliklerin frekans dağıımları analiz edilmiștir. Araștırma sonuçlarına göre; buğay bitkisi yetiștirilen tarım arazileri topraklarının çoğunluğu killi tınlı bünyeye sahiptir. Toprakların hacim ağırlığı değerlerinin \%65'i orta olarak belirlenmiștir. Buğday yetiștirilen toprakların \%85'inde tarla kapasitesi \%20 ile \%40 arasında değișmektedir. Topraklarda solma noktası ve bitkiye yarayıșlı su miktarı ortalama sırasıyla \%14.2; \%14.32 olarak belirlenmiștir. Dolayısıyla toprakların bünyesi, hacim ağırlığı, tarla kapasitesi gibi fiziksel özellikleri topraklardan yüksek verim elde edilmesini sınırlandıran faktörler olmamaktadır.

Buğay bitkisi yetiștirilen tarım arazileri topraklarının \%72.5'inin hafif alkali reaksiyonlu olup, topraklarda tuzluluk problemi olmaması araștırma topraklarının pek çok kültür bitkisinin yetistirilmesi için uygun koșullara sahip olduğunu göstermektedir. Toprakların büyük bir kısmı kireçsiz ve orta kireçli sınıfına girmekte, $\% 52.5^{\prime} i$ cok az ve az, \%42.5'i ise orta ve iyi düzeyde organik madde içermektedir. Araștırma topraklarının azot miktarı düșük ve orta düzeyde belirlenmiștir. Topraklarının çok büyük kısmı fosfor bakımından zengin olmadığından fosforlu gübrelemeye intiyaç gerekmektedir. Ova topraklarının potasyum kapsamı orta düzeydedir. Toprakların katyon değișim kapasitesi genellikle yüksek ve çok yüksektir. Araștırma topraklarının \%62.5'inde demir orta, \%100'ünde bakır çok yüksek, \%100'ünde mangan çok düșük ve düșük, \%80'inde çinko çok düșük düzeyde saptanmıștır.

\section{TEȘEKKÜR}

Doktora tezinin bir kısmı olan bu araștırmanın yürütülmesine yapmıș olduğu orijinal katkılarından dolayı Ondokuz Mayıs Üniversitesi Ziraat Fakültesi Toprak Bilimi ve Bitki Besleme Bölümü Öğretim Üyesi Prof. Dr. Coșkun GÜLSER' e teșekkür ederiz.

\section{KAYNAKLAR}

Anonim (1984). Samsun İli Verimlilik Envanteri ve Gübre İhtiyacı Raporu. Yayın No:23, Genel Yayın No:760, Ankara.
Anonim (2012). Samsun İli Tarım Mastır Planı. T.C. Samsun Il Özel İdaresi.

Anonymous (2016). International Grains Council (IGC), 2016. https://www.igc.org.uk

Anonim (2016). Türkiye İstatistik Kurumu Temel İstatistikler. http://www.tuik.gov.tr

Aydarov iP (1985). Regulirovaniye bodno-solevogo i pitatelnogo rejimov oroșayemı zemel, Press "Agropromizdat", 304, Moskova.

Bașar H (2001). Bursa ili topraklarının verimlilik durumlarının toprak analizleri ile incelenmesi. Uludağ Üniversitesi Ziraat Fakültesi Dergisi, 15(2): 69-83.

Bayraklı F (1987). Toprak ve Bitki Analizleri. Ondokuz Mayıs Üniversitesi Yayınları, No:17, Samsun.

Black C A (1965). Methods of soil analysis Part I-Physical and Mineralogical Methods, Soil Science Society of America, No: 9, USA.

Brohi AR, Aydeniz A, Karaman MR (1997). Toprak verimliliği (Genișletilmiș 2. Baskı). Türk Hava Kurumu Basımevi, 298, Ankara.

Campbell P (1985). Soil physics whit basic. Elsevier Press, Amsterdam.

Cantero-Martinez C, Angas P, Lampurlanes J (2007). Long-term yield and water use efficiency under various tillage systems in Mediterranean rainfed conditions. Annals of Applied Biology 150: 293-305.

Çimrin KM, Boysan S (2006). Van yöresi tarım topraklarının besin elementi durumları ve bunların bazı toprak özellikleriyle ilișkileri. Yüzüncü Yıl Üniversitesi Ziraat Fakültesi Tarım Bilimleri Dergisi, 16(2): 105-111.

Çolakoğlu H (1985). Gübre ve Gübreleme. Ege Üniversitesi Ziraat Fakültesi Yayınları, Teksir no: 17, Bornova, İzmir.

Demiralay i (1993). Toprak fiziksel analizleri. Atatürk Üniversitesi Ziraat Fakültesi Yayınları No:143, Erzurum.

Dengiz O, Ekberli i (2017). Bazı vertisol alt grup topraklarının fizikokimyasal ve ısısal özelliklerinin incelenmesi. Akademik Ziraat Dergisi, 6(1): 45-52.

Dengiz O, Göl C, Ekberli İ, Özdemir N (2009). Farklı Alüvial Teras Șekilleri Üzerinde Olușmuș Toprakların Dağıımı ve Özelliklerinin Belirlenmesi. Anadolu Tarım Bilimleri Dergisi, 24(3): 184-193.

Dengiz O, Gülser C (2014). Farklı Fluviyal Depozitler Üzerinde Olușmuș Toprakların Dağıım Alanlarının Belirlenmesi ve Sınıflaması, Türkiye Tarımsal Araștırmalar Dergisi, 1(1): 9-17.

Ekberli I, Dengiz O (2016). Bazı Inceptisol ve Entisol Alt Grup Topraklarının Fizikokimyasal Özellikleriyle Isısal Yayınım Katsayısı Arasındaki Regresyon İlișkilerin Belirlenmesi. Toprak Su Dergisi, 5(2): 1-10.

Ekberli i, Horuz A, Korkmaz A (2005). İklim faktörleri ve farklı azot dozlarının mısır bitkisinde verim ve azot kapsamına etkisi. Ondokuz Mayıs Üniversitesi Ziraat Fakültesi Dergisi, 20(1): 12-17. 
Ekberli i, Kerimova E (2005). Azerbaycan'ın Șirvan Bölgesinde Sulanan Killi Bir Toprağın Bazı Fiziksel-Kimyasal Parametrelerinin Değișimi. Ondokuz Mayıs Üniversitesi Ziraat Fakültesi Dergisi, 20(3): 54-59.

Ekberli i, Kerimova E (2008). Functional Relationships Between Fertility and Some Soil Parameters. Asian Journal of Chemistry, 20(3): 2320-2326.

Ekberli i, Dengiz O (2017). Bazalt ana materyali ve farklı topografik pozisyon üzerinde olușmuș toprakların bazı topografik özellikler ve fiziksel-kimyasal özellikleri arasındaki doğrusal regresyon modellerinin belirlenmesi. Toprak Su Dergisi, 6(1): 15-27.

Fageria NK, Baligar VC, Jones CA (1991). Growth And Mineral Nutrition Of Field Crops. Marcel Dekker Incorporated, 586, Newyork, USA.

Gülser C, Demir Z, İç S (2010). Changes in some soil properties at different incubation periods after tobacco waste application. Journal of Environmental Biology, 31 (5): 671-674.

Gülser C, Ekberli İ, Candemir F, Demir Z (2016). Spatial variability of soil physical properties in a cultivated field. Eurasian Journal Soil Science, 5(3): 192-200.

Gürsoy S, Sessiz A, Malhi SS (2010). Short-term effects of tillage and residue management following cotton on grain yield and quality of wheat. Field Crops Research, 119: 260268.

Heuscher SA, Brandt CC, Jardine PM (2005). Using soil physical and chemical properties to estimate bulk density. Soil Science Society of America Journal, 69(1): 51-56.

Hossain M F, Chen W, Zhang Yu (2015). Bulk density of mineral and organic soils in the Canada's arctic and subarctic. Information Processing In Agriculture, 2: 183-190.

İç S (2015). Carșamba Ovası Sol Sahil Topraklarında Yorgunluk Parametrelerinin Belirlenmesi. Doktora Tezi, Ondokuz Mayıs Üniversitesi Fen Bilimleri Enstitüsü Toprak ve Bitki Besleme Anabilim Dalı, 172, Samsun.

Jackson M.C (1962). Soil Chemical Analysis. Prentice Hall. Inc. Englewood Cliffs, New Jersey, USA.

Kacar B (1994). Bitki ve Toprağın Kimyasal Analizleri III, Toprak Analizleri. Ankara Üniversitesi Ziraat Fakültesi Eğitim Araștırma ve Geliștirme Vakfı Yayınları, No:3, Ankara.

Kauriçev is, Panov NP, Rozov NN, Stratonoviç MV, Fokin AD (1989). Pocvovedeniye. Press BO "Agropromizdat", Moskova.

Katkat A V, Celik N, Yürür N, Kaplan M (1987). Ekmeklik Cumhuriyet-75 Buğday Çeșidinin Azotlu Ve Fosforlu Gübre İsteğinin Belirlenmesi. Türkiye Tahıl Sempozyumu, 6-9 Ekim, Bursa.

Kendal E, Tekdal S, Aktaș H, Altıkat A, Karaman M, Baran i (2011). Diyarbakır Ekolojik Koșullarına Uygun Yabancı Yazlık Makarnalık Buğday Çeșitlerinin Belirlenmesi. Uludağ Üniversitesi, Ziraat Fakültesi, Türkiye VIII. Tarla Bitkileri Tarım Kongresi, Cilt 1- sayfa:242-245, 12- 25 Ekim, Bursa.

Kettlewell PS, Griffiths MW, Hocking TJ, Wallington DJ (1998). Dependence of wheat dough extensibility on flour sulphur and nitrogen concentrations and the influence of foliar applied sulphur and nitrogen fertilisers. Journal of Cereal Science, 28: 15-23.

Kün E (1996). Tahıllar-ı Serin İklim Tahılları. Ankara Üniversitesi Ziraat Fakültesi Yayınları, Yayın No: 1451, Ankara.

Lindsay L, Norvell WA (1978). Development of a DTPA soil test for zinc, iron, manganese and copper. Soil Science Society of American Proceeding 42: 421-428.

Machado S, Petrie S, Rhinhart K, Qu A (2007). Long-term continuous cropping in the Pacific Northwest: tillage and fertilizer effects on winter wheat, spring wheat, and spring barley production. Soil and Tillage Research 94, 473-481.

Martin MA, Reyes M, Taguas FJ (2017). Estimating soil bulk density with information metrics of soil texture. Geoderma, 287: 66-70.

Martínez E, Fuentes JP, Silva P, Valle S, Aceved E (2008). Soil physical properties and wheat root growth as affected by no-tillage and conventional tillage systems in a Mediterranean environment of Chile. Soil and Tillage Research, 99(2): 232-244.

Olsen SR, Cole V, Watanabe FS, Dean LA (1954). Estimation of Available Phosphorous in Soils by Extraction with Sodium Bicarbonate. USDA Circular, 9398: 1-19.

Özdemir Ö, Gülser C, Ekberli İ, Kop ÖT (2014). Asit toprakta düzenleyici uygulamalarının bazı toprak özellikleri ve verime etkileri. / Toprak Bilimi ve Bitki Besleme Dergisi, 2(1): 27-32

Özyazıcı MA, Dengiz O, Aydoğan M, Bayraklı B, Kesim E, Urla Ö, Yıldız H, Ünal E (2016). Orta ve Doğu Karadeniz bölgesi tarım topraklarının temel verimlilik düzeyleri ve alansal dağılımları. Anadolu Journal of Agricultural Sciences, 31(1): 136-148.

Parlak M, Fidan A, Kızılcık I, Koparan H (2008). Eceabat ilçesi (Çanakkale) tarım topraklarının verimlilik durumlarının belirlenmesi. Tarım Bilimleri Dergisi, 14(4): 394-400.

Richards LA (1954). Diagnosis and Improvement of Saline and Alkali Soils. United States Department of Agriculture. Handbook, 60: 105-106.

Sağlam MT (1997). Toprak ve Suyun Kimyasal Analiz Yöntemleri. Tekirdağ Üniversitesi Ziraat Fakültesi Yayınları, No: 189

Smith GP, Googing MJ (1999). Models of wheat grain quality considering climate, cultivar and nitrogen effects. Agricultural and Forest Meteorology, 94(1): 86-93.

Seker C, Karakaplan S (1999). Konya ovasında toprak özellikleri ile kırılma değerleri arasındaki ilișkiler. Turkish Journal of Agriculture and Forestry, 23: 183-190.

Taban S, Alpaslan M, Hashemi AG, Eken D (1997). Orta Anadolu'da çeltik tarımı yapılan toprakların bazı fiziksel ve kimyasal özellikleri. Mühendislik Bilimleri Dergisi, 3(3): 457466.

Turan MA, Katkat AV, Özsoy G, Taban S (2010). Bursa ili alüviyal tarım topraklarının verimlilik durumları ve potansiyel beslenme sorunlarının belirlenmesi. Uludağ Üniversitesi Ziraat Fakültesi Dergisi, 24(1): 115-130. 
Tümsavaș Z (2002). Bursa ili kolüvyal büyük toprak grubu topraklarının verimlilik durumunun belirlenmesi. Anadolu, Journal of Agean Agricultural Research Institute, 12(1): 131144.

Tümsavaș Z, Aksoy E (2009). Kahverengi orman büyük toprak grubu topraklarının verimlilik durumlarının belirlenmesi. Uludağ Üniversitesi Ziraat Fakültesi Dergisi, 23(1): 93-104.

United States Salinity Laboratory Staff (1954). Diagnosis and Improvement of Saline and Alkali Soils, Agriculture. Handbook No:60, USDA.

Ülgen N, Yurtsever N (1988). Türkiye Gübre Ve Gübreleme Rehberi (3. Baskı). Toprak ve Gübre Araștırma Enstitüsü Yayınları No. 151, 182, Teknik Yayınlar No: T-59, Ankara.
Wilson MG, Sasal MC, Caviglia OP (2013). Critical bulk density for a Mollisol and a Vertisol using least limiting water range: Effect on early wheat growth. Geoderma, 192: 354361.

Xu ZZ, YU ZW, Wang D, Zhang YL (2005). Nitrogen Accumulation and Translocation for Winter Wheat under Different Irrigation Regimes. J. Agronomy\&Crop Science 191, 439-449.

Zengin M, șeker C (2003). Buğday bitkisinin besin elementi kapsamı ile toprak özellikleri arasındaki regresyon ilișkiler. Selçuk Üniversitesi Ziraat Fakültesi Dergisi, 17(31): 31-35. 


\title{
Tuz Stresi Altında Yetiștirilen Patlıcan Bitkilerinde Klorofil, Yaprak Su Potansiyeli ve Bazı Meyve Özellikleri Üzerine Așılı Bitki Kullanımının Etkisi
}

\author{
Manar Talhouni' \\ Șebnem Kușvuran² \\ Sevinç Kıran ${ }^{3, *}$

\begin{abstract}
'National Center for Agricultural Research and Extension, Amman
\end{abstract} \\ ${ }^{2}$ Çankırı Karatekin Üniversitesi, Kızılırmak Meslek Yüksekokulu, Çankırı \\ ${ }^{3}$ Toprak Gübre ve Su Kaynakları Merkez Araștırma Enstitüsü, Ankara \\ ${ }^{4}$ Ankara Üniversitesi, Ziraat Fakültesi, Bahçe Bitkileri Bölümü, Ankara
}

Ș. Șebnem Ellialtıoğlu

\begin{abstract}
*Sorumlu yazar e-mail (Corresponding author e-mail): sevinckiran@tgae.gov.tr Geliș tarihi (Received) : 13.12.2018

Kabul tarihi (Accepted): 04.03.2019

DOI : 10.21657/topraksu.544665
\end{abstract}

\section{Öz}

Tuzluluğa bağı verim ve kalite kaybı diğer sebzelerde olduğu gibi patıcan için de önemli bir sorundur. Patlıcan (Solanum melongena L.), tuza karșı orta derecede hassas bir bitkidir. Tuzluluk stresinin neden olduğu, verim kaybını ortadan kaldırmak veya azaltmak için kullanılan önemli yöntemlerden biri așılamadır. Araștırmada Vista, AGR703 (S. aethiopicum), Köksal $F_{1}$, Yula $F_{1}$, Vista (S. incanum x S. melongena hybrids) ve Hawk (S. torvum) ile tuza ve kurağa tolerant olduğu bilinen Mardin ve Burdur ıslah hatları (S. melongena L.) anaç olarak; tuza hassas Artvin yerel genotipi ile Naomi F, çeșidi kalem olarak kullanılmıștır. Kalem olarak kullanılan çeșitler ile așısız, kendi üzerine ve anaçlar üzerine așılanarak 18 anaç/kalem kombinasyonu olușturulmuștur. Bitkilerin yetiștirilmesinde damla sulama yöntemi kullanılarak, EC 1.8-2.0 dSm-1 ve pH 5-6 özelliğindeki su ile (kontrol suyu) sulanma yapılmıștır. Bitkiler çiçeklenme ve meyve tutumu așamasına geldiğinde 3 bin litrelik PE (polietilen) depo içine $8.76 \mathrm{~kg} \mathrm{NaCl}$ (90 mM) ilave edilmiș (EC 6-7 dSm${ }^{-1}$ ) ve bu depodan stres grubu bitkilere bir gün tuzlu su, bir gün kontrol suyu verilmiștir. Araștırma sonucunda; klorofil içeriği, toplam verim, ortalama meyve ağırlığı, meyve suyu $\mathrm{pH}$ değeri, toplam suda çözünebilir madde miktarı, titre edilebilir asit miktarı ve meyvelerde renk ölçümü değerleri bakımından uygulama çeșit interaksiyonu istatistiki olarak önemli bulunmuștur. Bununla birlikte ortalama meyve çapı değerleri bakımından kombinasyon ve uygulamalar arası, yaprak su potansiyeli değerleri bakımından uygulamalar arası farklıık önemli bulunmuștur. Kalem olarak kullanılan Naomi $F_{1}$ ticari çeșidi, Artvin yerel genotipine göre daha iyi sonuçlar verdiği, anaç olarak kullanılan ticari çeșitler içinde Köksal $F_{1}$ ve Vista $F_{1}$ çeșitlerinin öne çıktığı belirlenmiștir. Sonuç olarak anaç olarak kullanılan Burdur ıslah hattının anaç ıslahında kullanılabilecek bir genotip olduğu tespit edilmiștir.

Anahtar kelimeler: Patlıcan, stres, așı, anaç

\section{Effects of Grafting on Eggplants Grown under Salinity Stress in Terms of Chlorophyll Content, Leaf Water Potential and Some Fruit Characteristics}

\begin{abstract}
Eggplant (Solanum melongena L.); the third most important vegetable crop after potato and tomato; is relatively salt sensitive. Grafting over tolerant rootstocks proved to be an effective tool, among others, to alleviate negative effects of salinity upon vegetable crops by increasing plants tolerance against salinity. In this study, different rootstock/scion eggplant combinations were obtained as follow; Five
\end{abstract}


commercial rootstocks (AGR 703 (S. aethiopicum), Vista, Köksal $F_{1}$, Yula $F_{1}$ (S. incanum x S. melongena hybrids) and Hawk (S. torvum)), in addition to two Turkish genotypes Burdur and Mardin (S. melongena L.) were used as the rootstocks. For scion two cultivars were used (Artvin and Naomi $F_{1}$ ). Self-grafted and non-grafted seedlings were used as control. In total 18 combinations were obtained. Grafted plants where grown under two salinity treatments 1.8-2 dSm${ }^{-1}$ (control) and 5-6 dSm${ }^{-1}$ (stress) in pots under greenhouse conditions. Salinity treatment started when plants were at the flowering stage by adding $\mathrm{NaCl}$ to the nutriontion solution applied through drip irrigation system. $\mathrm{NaCl}$ was used as the salinity source by adding $8.76 \mathrm{Kg} \mathrm{NaCl}(90 \mathrm{mM})$ to 3000 lit irrigation tank designated to plants group under stress. Plants in the stress treatment were irrigated with saline water every other day. Total yield, average fruit weight, leaf chlorophyll content, fruit total soluble solids (TSS) and titratable acidity (TA), fruit weight and diameter, fruit color and $\mathrm{pH}$ parameters were tested and the genotype $\mathrm{x}$ treatment interaction was found to be significant. Salinity had negative effects on the parametrers measured. In terms of average fruit diameter values, significant differences were found between treatment (salinity) and grafting combinations, in addition the difference between the treatments in terms of leaf water potential values was found to be significant. Naomi Fi genotype was found superior compared to Artvin genotype as a scion, while between rootstocks Köksal $F_{\text {, }}$ and Vista $F_{\text {, genotypes were found }}$ significantly superior among the other comercial genotypes used.

Key word: Eggplant, stress, grafting, rootstock

\section{Gíriș}

Patlıcan, dünyada 1.871 milyon hektar alanda 50.193 milyon ton, Türkiye'de yaklașı 27 bin hektar alanda 827 bin ton olarak üretilen, Solanaceae familyasına ait, ticari değere sahip olduğu kadar içerdiği vitaminler, antioksidanlar, mineral maddeler ile sağık yönünden de değerli bir sebzedir (TUIK 2017). Tropik ve subtropik ekolojilerde ve Akdeniz havzasında bolca yetiștirilen bir sebze türüdür. Hindistan'ın da içinde yer aldığı Hint Yarımadası kökenli bir tür olarak bilinen patlıcanın; Çin, Hindistan veya Tayland'da kültüre alındığı tahmin edilmektedir. Anadolu'ya İpek Yolu ile yapılan ticaret sayesinde geldiği tahmin edilmekte olup geçmișten günümüze hem sebze hem de tıbbi bitki olarak kullanılmıștır (Daunay ve Janick, 2007; Boyacı 2008). Türkiye'deki patlıcan üretiminin yaklașık \%20'si örtü altında yapılmaktadır. Taze olarak tüketildiği gibi kurutularak, közlenerek, ve dondurularak muhafaza edilmektedir (Çürük vd., 2010; Tümbilen vd., 20111.

Sebze tarımının yoğun olarakyapııdığı alanlarda verim ve kalite kaybına yol açan en önemli faktörlerden biri toprak tuzluluğudur. Abiyotik stres faktörlerinden olan tuzluluğa tolerant çeșit ıslahındaki bașarı her zaman istenilen düzeyde olamamaktadır. Abiyotik streslere tolerans amaçlandığında ıslah süresi uzun ve zorlayıcıdır. Ayrıca kalıtımın çok genli, kantitatif bir özellik olması sebebiyle hedefe kolayca ulașmak her

zaman mümkün değildir. Anaç kullanımı ve așılı bitki ile yapılan yetiștiricilik, alternatif bir çözüm olarak öne çıkmaktadır. Anaç üzerine așılanmıș fidelerin kullanıldığı sebze yetiștiriciliği birçok türde biyotik ve abiyotik stres faktörleri ile bașa çıkmada etkin bir yol olarak düșünülmektedir.

Tuzluluk, özellikle kurak ve yarı kurak iklimlerde bitki gelișimini ve ürün verimini etkileyen en yaygın çevresel tehditlerden bir tanesidir (Turhan vd., 2009; Colla vd., 2010). Tuzluluk örtü altı yetiștiricilik alanlarında, açıkta yetiștiricilikten çok daha etkin olmaktadır. Topraksız sistemlerde dahi düșük kaliteli su kullanımı tuzluluk açısından sorunlara neden olmaktadır (Oztekin, 2011). Așılama, sebze yetiștiriciliğinde ilk olarak abiyotik stres koșullarına karșı kullanılımıștır (Eisavd., 2012). Așlı bitkiler, güçlü kök yapıları sayesinde tuz stresine karșı dayanıkılıık göstermektedir (Fernandez-Garcia vd.,2003; Estan vd., 2005). Kalem ya da çeșit, meyve verim ve kalitesinden sorumlu etken iken anaç, kök sisteminde avantajlar sağlamakta, bununla birlikte ürün üzerinde etkilere sahip olabilmektedir. Bu yüzden anaç-kalem kombinasyonları, iklim ve yer özellikleri dikkate alınarak doğru tespit edilmelidir. Sebzelerde așilamada kullanılan anaçların büyük çoğunluğu aynı türün yabani formları olup, bu yabani formlar arasında tür içi veya türler arası melezlemeler ile elde edilmiș hibrit anaçlar güçlü yapılarından dolayı fayda sağlamaktadır (Savvas vd., 2010; King vd., 2010). 
Patlıcanda așılı bitki kullanımının ve anaç/kalem kombinasyonlarının tuz stresine toleransı artırma üzerindeki etkilerinin incelendiği bu araștırmada; patlıcanda ticari olarak kullanılan ve yabani tür kökenli anaçlar ile tuza toleranslı yerel patıcan genotipleri üzerine yapılan așılamanın, tuz stresi altında yetiștirilen tuza hassas bir yerel genotip ve ticari bir F1 patlıcan çeșidinin tuzdan etkilenme durumunu ortaya koymak amaçlanmıștır. Burada sunulan sonuçlar, farklı anaç/kalem kombinasyonlarında tuz uygulamalarının klorofil, yaprak su potansiyeli ve bazı meyve özelliklerine olan etkilerini kapsamaktadır.

\section{MATERYAL VE YÖNTEM}

Araștırma 2014 yılında Antalya'da plastik örtülü araștırma serasında yürütülmüștür. Araștırmada kullanılan bitkisel materyal olarak Vista (S. melongena), AGR703 (S.torvum), Köksal F1 (S. aeriticum $x$ S.melongena), Yula $F_{1}$ (S. incanum $x$ S. melongena hibritleri ), Hawk (S.torvum) ticari patlıcan anaçları ile tuza ve kurağa tolerant olduğu bilinen (Yașar, 2003), Mardin ve Burdur ıslah hatları (anaç olarak) ve tuza hassas Artvin yerel genotipi ile Naomi $F_{1}$ ticari çeșidi (kalem olarak) kullanıımıștır. Naomi $F_{1}$ ve Artvin genotiplerinin anaçlarla ayrı ayrı așılanmasıyla olușturulan 14 kombinasyona ilaveten tek bașına așılama ișleminin tuz toleransına etkisini belirlemek için kendi üzerine așllı 2 kombinasyon daha elde edilmiștir. Ayrıca anaç etkisini belirlemek amacıyla kalemler așısız olarak da çalıșmaya dahil edildiğinde toplam 18 farklı kombinasyon ortaya çıkmıștır. Așılı ve așısız tüm patlıcan fideleri, 1:1 oranında perlit: vermikulit içeren 8 L'lik saksılara dikilmiștir. Olușturulan kombinasyonlar kontrol ve tuz uygulaması olarak tesadüf parselleri deneme desenine göre iki gruba ayrılmıș, üç tekerrürlü, her tekerrürde 3 bitki, sıra arası $80 \mathrm{~cm}$ ve sıra üzeri 60 $\mathrm{cm}$ olacak șekilde rastgele yerleștirilmiștir. Her iki grup, dikimden itibaren 40 gün boyunca Hoagland besin çözeltisi $\left(\mathrm{KNO}_{3}: 1020 \mathrm{ppm}, \mathrm{Ca}\left(\mathrm{NO}_{3}\right)_{2}\right.$ : $492 \mathrm{ppm}, \mathrm{NH}_{4} \mathrm{H}_{2} \mathrm{PO}_{4}: 230 \mathrm{ppm}, \mathrm{MgSO}_{4} \cdot 7 \mathrm{H}_{2} \mathrm{O}$ : 420 ppm, $\mathrm{H}_{3} \mathrm{BO}_{3}: 2.86 \mathrm{ppm}, \mathrm{MnCl}_{2} \cdot 4 \mathrm{H}_{2} \mathrm{O}: 1.81$ ppm, $\mathrm{H}_{2} \mathrm{MoO}_{4} \cdot \mathrm{H}_{2} \mathrm{O}: 0.09 \mathrm{ppm}, \mathrm{FeSO}_{4} \cdot \mathrm{H}_{2} \mathrm{O}: 0.07$ ppm, $\left.(\mathrm{CHOH})_{2}(\mathrm{COOH})_{2}: 0.02 \mathrm{ppm}\right)$ ile sulanmıș olup bitkilerin tek gövde üzerinde normal olarak dallanmasına izin verilmiștir. Damla sulama yönteminde kullanılan su, yeraltı su kuyusundan elde edilmiștir ve bu suya ait özellikler EC 1.8-2.0 dS $\mathrm{m}^{-1}$; $\mathrm{pH}$ 5-6'dır. Bitkiler çiçeklenme ve meyve tutumu așamasına gelindiğinde 3 bin litrelik PE su deposu içine $8.76 \mathrm{~kg} \mathrm{NaCl}(90 \mathrm{mM}$; EC 6-7 $\mathrm{dS} \mathrm{m}^{-1}$ ) ilave edilmiș ve bu depodan stres grubu bitkilere bir gün tuzlu su bir gün kontrol suyu verilmiștir. Așırı tuz birikimini önlemek amacıyla saksı altlarından serbest drenaj uygulanmıștır. Saksı altlıklarında toplanan sular, ortamdaki EC dozunu sabit tutmak amacıyla EC metre yardımıyla her sulama sonrası ölçülmüștür. İlk hasat yapıldığında (tuzlu sulama uygulamasından 40 gün sonra), içeriği zenginleștirilmiș olan ikinci besin çözeltisi kullanıımaya bașlanmıștır. Besin çözeltilerinin belirlenmesinde Libia vd. (2012), Aktas vd. (2013) ile Genta Tarım A.Ș. yetiștiricilik uygulamalarından yararlanılmıștır (Karaçalı, 1993; Altunlu, 2011).

\section{Ölçüm ve Analizler:}

Klorofil içeriği: İkinci meyve hasadının yapıldığı dönemde bitkinin büyüme ucundan geriye doğru alınan üçüncü yapraktan hazırlanan 200 mg örnek, \%80'lik asetonda homojenize edilmiștir. Filtrasyondan sonra aseton ile 10 ml'ye tamamlanan örneklerde spektorfotometrede (Analytic jenan 40) 652 nm'de ölçüm yapılımıștır.

Klorofil miktarı = ABS değerix2.78xHacim 110 ml) /Taze AğırlıkX1000 formülü ile hesaplanmıștır.

Yaprak su potansiyeli: Bitkilerden alınan yaprak örneklerinde Model 1000 PMS Instrument Com. cihazı ile ölçümler yapılarak, yaprak su potansiyelleri belirlenmiștir.

Bitki bașına toplam verim (kg/bitki): Her uygulama konusuna ait bitkilerde ilk hasattan son hasat tarihine kadar olan süre içerisinde toplanan meyveler tartılarak toplam değeri bulunmuș ve bu değer bitki sayısına bölünmüștür.

Ortalama meyve ağırlığı (g): Her bir uygulama konusundan hasat edilen tüm meyvelerin ağırıkları meyve sayısına bölünerek hesaplanmıștır ve $g$ olarak ifade edilmiștir.

Ortalama meyve çapı (mm): Uygulamalara ait bitki örneklerinden hasat edilen tüm meyvelerin orta noktalarından dijital kumpas ile çapları ölçülmüștür ve mm olarak ifade edilmiștir.

Meyve kalitesini belirlemek amacıyla, bitki üzerinde 2. salkımda olușan meyveler antezis döneminden itibaren 4 haftalık olduklarında hasat edilerek analizler yapılmıștır. Meyve örnekleri blender ile parçalanmıș ve elde edilen meyve püreleri filtre kağıdından geçirilerek süzülmüștür (Altunlu, 2011). Buna göre; 
Meyve suyu pH değeri: Süzüğe batırılan el tipi WTW pH metre probu ile yapılan ölçümler sonucunda elde edilmiștir.

Toplam suda çözünebilir madde miktarı (TSÇKM) (\%): Süzükten alınan birkaç damla örnek dijital el refraktometresi ile okunmuș ve sonuçlar \% olarak verilmiștir.

Titre edilebilir asit (TA) miktarı (mval/100 $\mathbf{m l}$ ): Süzükten alınan $5 \mathrm{ml}$ örneğe $10 \mathrm{ml}$ saf su konmuș, 0.1 N NaOH çözeltisi ile 8.01 pH değeri elde edilinceye kadar titrasyon yapılmıștır. Titre edilebilir asit değeri, harcanan $\mathrm{NaOH}$ miktarı üzerinden formülle hesaplanmıștır (Karaçalı, 1993; Altunlu,2011).

Meyvelerde renk ölçümü: Meyve dıș rengi belirleme çalıșmalarında Konika Minolta CR 200 renkölçer cihazından faydalanıımıștır. Minolta cihazı ile yapılan ölçümlerde Sönmez (2014) tarafından açıklanan yöntem ve formülasyon kullanıımıștır.

\section{BULGULAR VE TARTIȘMA \\ Klorofil miktarı bakımından ortaya çıkan değișimler}

Tuz uygulamasından 60 gün sonra bitkilerden alınan örneklerde yapılan ölçümler sonucu klorofil konsantrasyonunda kontrol bitkilerine göre azalma belirlenmiș ve değerler $44.47 \pm 0.03$ $\mu \mathrm{g} / \mathrm{mg}$ TA (Köksal/Artvin) ile 39.43 $\pm 0.21 \mu \mathrm{g} / \mathrm{mg}$ TA (Naomi) arasında bulunmuștur (Çizelge 1). Uygulamalar arasındaki ve așı kombinasyonları arasındaki farklılık istatistiksel olarak $p \leq 0.01$ düzeyinde önemlilik göstermiș, 'uygulama $x$ kombinasyon' interaksiyonu da önemli bulunmuștur. Kendi üzerine așılı bitkilerin klorofil miktarları en düșük gruplara (așısız olanlar) yakın istatistiksel değerler vermiștir. Elde edilen değerler önceki çalıșmalarla benzerlik göstermektedir.

Çizelge 1. Tuz uygulamasından 60 gün sonra klorofil miktarı ( $\mu \mathrm{g} / \mathrm{mg}$ TA) ve yaprak su potansiyeli (-bar) değerleri Table 1. Chlorophyll content ( $\mathrm{gg} / \mathrm{mg}$ FW) and leaf water potential (-bar) values 60 days later after salt treatment

\begin{tabular}{|c|c|c|c|c|}
\hline \multirow{2}{*}{ Kombinasyonlar } & \multicolumn{2}{|c|}{ Klorofil ( $\mu \mathrm{g} / \mathrm{mg}$ ) } & \multicolumn{2}{|c|}{ Yaprak Su Potansiyeli (-bar) } \\
\hline & Kontrol & Tuz & Kontrol & Tuz \\
\hline Köksal/Artvin & $52.47 \pm 1.90 \mathrm{~h}$ & $44.47 \pm 0.03 k$ & $13.43 \pm 0.81 \mathrm{a}$ & $17.54 \pm 3.62 \mathrm{a}$ \\
\hline AGR703/Artvin & $49.82 \pm 0.07 \mathrm{~g}$ & $44.42 \pm 0.03 k$ & $13.04 \pm 1.30 \mathrm{a}$ & $17.08 \pm 3.93 \mathrm{a}$ \\
\hline Vista/Artvin & $48.55 \pm 0.13 \mathrm{~d}-\mathrm{g}$ & $43.62 \pm 0.07 \mathrm{hi}$ & $12.45 \pm 2.91$ а & $16.46 \pm 1.47 \mathrm{a}$ \\
\hline Yula/Artvin & $47.43 \pm 0.08$ a-d & $41.85 \pm 0.17$ ef & $13.65 \pm 1.16$ a & $17.59 \pm 2.01 \mathrm{a}$ \\
\hline Burdur/Artvin & $49.01 \pm 0.01 \mathrm{e}-\mathrm{g}$ & $44.16 \pm 0.06 \mathrm{jk}$ & $13.43 \pm 1.59$ a & $17.18 \pm 2.91 \mathrm{a}$ \\
\hline Mardin/Artvin & $48.19 \pm 0.04 c-f$ & $43.30 \pm 0.08 \mathrm{~h}$ & $12.67 \pm 1.98$ a & $16.76 \pm 1.44 a$ \\
\hline Hawk/Artvin & $48.37 \pm 0.06 c-f$ & $43.48 \pm 0.04$ hi & $12.54 \pm 2.94$ а & $16.69 \pm 2.08$ a \\
\hline Artvin/Artvin & $47.12 \pm 0.08$ a-c & $41.14 \pm 0.36 d$ & $12.55 \pm 2.72$ а & $18.30 \pm 3.00$ a \\
\hline Artvin & $46.68 \pm 0.03 \mathrm{ab}$ & $40.08 \pm 0.33 \mathrm{~b}$ & $13.04 \pm 3.52$ a & $19.68 \pm 2.56$ a \\
\hline Köksal//Naomi & $49.48 \pm 0.20 \mathrm{fg}$ & $44.35 \pm 0.05 k$ & $12.76 \pm 2.02 \mathrm{a}$ & $16.68 \pm 2.63 \mathrm{a}$ \\
\hline AGR703/Naomi & $48.85 \pm 0.05 \mathrm{e}-\mathrm{g}$ & $43.70 \pm 0.00 \mathrm{hi}$ & $12.88 \pm 0.95 a$ & $16.67 \pm 1.09$ a \\
\hline Vista/Naomi & $48.10 \pm 0.00 c-f$ & $42.84 \pm 0.14 \mathrm{~g}$ & $13.35 \pm 2.40$ а & $17.18 \pm 1.90$ a \\
\hline Yula/Naomi & $47.68 \pm 0.08$ a-e & $42.17 \pm 0.06 \mathrm{f}$ & $12.31 \pm 3.17$ a & $17.34 \pm 0.94$ a \\
\hline Burdur/Naomi & $48.93 \pm 0.06 \mathrm{e}-\mathrm{g}$ & $43.89 \pm 0.08 \mathrm{ij}$ & $13.53 \pm 2.21$ a & $17.83 \pm 2.81$ a \\
\hline Mardin/Naomi & $48.00 \pm 0.10$ b-e & $42.63 \pm 0.08 \mathrm{~g}$ & $13.87 \pm 2.34$ а & $19.47 \pm 1.41 \mathrm{a}$ \\
\hline Hawk/Naomi & $47.28 \pm 0.03$ a-d & $41.55 \pm 0.13 \mathrm{de}$ & $12.45 \pm 3.42 \mathrm{a}$ & $15.92 \pm 0.33$ a \\
\hline Naomi/Naomi & $47.00 \pm 0.01$ a-c & $40.55 \pm 0.05 \mathrm{c}$ & $12.98 \pm 1.08$ а & $18.70 \pm 0.46 a$ \\
\hline Naomi & $46.53 \pm 0.06$ a & $39.43 \pm 0.21$ a & $13.33 \pm 3.21$ a & $19.86 \pm 2.03$ a \\
\hline$C V(\%)$ & 2.09 & 3.69 & 3.60 & 6.57 \\
\hline Uygulama & \multicolumn{2}{|c|}{$* *$} & \multicolumn{2}{|c|}{$* *$} \\
\hline Kombinasyon & \multicolumn{2}{|c|}{$\star *$} & \multicolumn{2}{|c|}{ ÖD } \\
\hline Kombinasyon X & \multirow{2}{*}{\multicolumn{2}{|c|}{$* *$}} & \multirow{2}{*}{\multicolumn{2}{|c|}{ ÖD }} \\
\hline Uygulama & & & & \\
\hline
\end{tabular}

Aynı sütunda farklı harfi alan ortalamalar arasındaki farklılık önemlidir ( $\mathrm{\rho} \leq 0.01)$. Ortalamalar arası farklııklar Duncan testi ile belirlenmiștir. **: P $\leq 0.01$ olasıllık düzeyinde önemlidir. *: P $\leq 0.05$ olasılık düzeyinde önemlidir. ÖD: önemli değil 
Tuz stresinde yapraklarda renk açılması, sararma ve en sonunda nekroze olan dokular tipik belirtilerdir. Klorofil miktarının tuz stresi altındaki bitkilerde azalmasının nedeni fotosentetik sistemin fonksiyonunu yitirmesidir. Böylece yașlanma meydana gelmiș, klorofil parçalanmıș ve fotosentez oranı düșmüștür (Sivritepe vd., 2010; Yașar vd., 2011 ; Sangtarashani vd., 2013).

\section{Yaprak su potansiyeli bakımından ortaya çıkan değișimler}

Așılı ve așısız pattıcan bitkilerinden olușturulan 18 farklı kombinasyona sahip kontrol ve tuz grubu arasındaki ve așı kombinasyonları arasındaki farklılık istatistiksel olarak $p \leq 0.01$ düzeyinde önemli bulunmuștur. Kontrol uygulamasındaki kombinasyonlar istatistiksel olarak aynı grup içerisinde yer almıșlardır. Tuz uygulaması yapılmayan bitkilerdeki yaprak su potansiyeli -12.45 ila -13.87 bar arasında değișirken, tuz uygulanan bitkilerde $-15.92 \pm 0.33$ ila $-19.86 \pm 2.03$ bar arasında değișmiștir. Tuzlu ortam bitkilerin yaprak su potansiyel değerlerinde azalmaya neden olmuștur. Bulunan sonuçlar önceki araștırma sonuçları ile uyumludur. Bitki stres koșulları altında madde birikimi sayesinde ozmotik potansiyelini düșürür ve su alım kapasitesinin artırır. Böylece turgor basıncı artar, hücre gelișmesi ve stomaların açılması sağlanır. Domateste (RomeroAranda vd.,2001; Hossain vd., 2012), kavunda (Kușvuran vd., 2011 ) tuz stresinin bitkilerde yaprak su potansiyelini azalttığını bildirmișlerdir.

\section{Meyve kabuk renk ölçümleri bakımından ortaya çıkan değișimler}

Kabuk renk değerleri (Chroma) bakımından 'uygulamaxkombinasyon' interaksiyonu önemli bulunmuștur. Anaçlar üzerine așılama yapıIması meyve rengi üzerinde farklıık yaratan bir etki olarak ortaya çıkmıș, bu etki kendi üzerine așılanan Artvin ve Naomi çeșitlerinde de meydana gelmiștir (Çizelge 2). Uygulamalar arasındaki ve așı kombinasyonları arasındaki farklılık istatistiksel olarak $p \leq 0.01$ düzeyinde önemlilik gösterdiği gibi, bu özellik bakımından 'uygulamaxkombinasyon' interaksiyonu da önemli bulunmuștur.

Çizelge 2. Tuz stresi uygulaması sonunda chroma ve hue açısı değerleri

Table 2. At the end of salt stress treatment, chroma and hue angle values

\begin{tabular}{|c|c|c|c|c|}
\hline \multirow{2}{*}{ Kombinasyonlar } & \multicolumn{2}{|c|}{ Chroma } & \multicolumn{2}{|c|}{ Hue } \\
\hline & Kontrol & Tuz & Kontrol & Tuz \\
\hline Köksal/Artvin & $15.31 \pm 1.74 \mathrm{C}$ & $21.01 \pm 2.05 \mathrm{~g}$ & $11.13 \pm 0.75 a$ & $9.15 \pm 1.66 \mathrm{ab}$ \\
\hline AGR703/Artvin & $15.73 \pm 1.71 \mathrm{C}$ & $19.11 \pm 2.04 \mathrm{fg}$ & $22.28 \pm 2.64 c$ & $17.07 \pm 1.61 \mathrm{ef}$ \\
\hline Vista/Artvin & $15.05 \pm 0.98 \mathrm{c}$ & $19.19 \pm 2.74 \mathrm{fg}$ & $23.99 \pm 2.66 \mathrm{~cd}$ & $18.75 \pm 1.65 \mathrm{fg}$ \\
\hline Yula/Artvin & $6.93 \pm 1.07$ а & $9.20 \pm 1.18 \mathrm{ab}$ & $14.27 \pm 2.17 \mathrm{ab}$ & $10.34 \pm 1.16$ a-c \\
\hline Burdur/Artvin & $16.14 \pm 1.12 \mathrm{C}$ & $19.28 \pm 2.25 \mathrm{fg}$ & $24.18 \pm 3.84 \mathrm{~cd}$ & $20.36 \pm 2.35 \mathrm{~g}$ \\
\hline Mardin/Artvin & $10.24 \pm 1.04 \mathrm{~b}$ & $14.22 \pm 2.09 \mathrm{~cd}$ & $15.26 \pm 1.31 \mathrm{~b}$ & $13.01 \pm 1.98 \mathrm{~cd}$ \\
\hline Hawk/Artvin & $16.58 \pm 1.17 \mathrm{C}$ & $18.38 \pm 1.53 \mathrm{e}-\mathrm{g}$ & $27.14 \pm 2.15 \mathrm{~d}$ & $19.45 \pm 1.83 \mathrm{fg}$ \\
\hline Artvin/Artvin & $6.39 \pm 0.86$ a & $6.83 \pm 1.15 a$ & $13.41 \pm 2.15 \mathrm{ab}$ & $8.23 \pm 1.67 a b$ \\
\hline Artvin & $15.22 \pm 2.26 \mathrm{c}$ & $16.73 \pm 1.40 \mathrm{~d}-\mathrm{f}$ & $13.97 \pm 2.85 \mathrm{ab}$ & $9.68 \pm 2.02 \mathrm{ab}$ \\
\hline Köksal/Naomi & $10.87 \pm 1.43 \mathrm{~b}$ & $11.93 \pm 1.31 \mathrm{bc}$ & $15.35 \pm 2.91 \mathrm{~b}$ & $10.53 \pm 2.08$ a-c \\
\hline AGR703/Naomi & $6.38 \pm 0.49$ а & $7.26 \pm 1.15$ a & $13.16 \pm 1.05 \mathrm{ab}$ & $7.66 \pm 1.08$ a \\
\hline Vista/Naomi & $6.17 \pm 0.89$ а & $6.99 \pm 0.97$ а & $13.52 \pm 1.49 \mathrm{ab}$ & $8.31 \pm 0.87$ ab \\
\hline Yula/Naomi & $6.32 \pm 1.43$ a & $6.62 \pm 0.81$ a & $13.34 \pm 2.98 \mathrm{ab}$ & $8.32 \pm 1.31 \mathrm{ab}$ \\
\hline Burdur/Naomi & $6.12 \pm 1.12$ a & $7.21 \pm 1.49$ a & $12.57 \pm 2.61 \mathrm{ab}$ & $8.95 \pm 2.26$ ab \\
\hline Mardin/Naomi & $9.55 \pm 1.26 \mathrm{~b}$ & $11.37 \pm 1.31 \mathrm{~b}$ & $14.93 \pm 1.85 \mathrm{ab}$ & $9.49 \pm 1.08$ ab \\
\hline Hawk/Naomi & $6.62 \pm 1.06$ a & $7.46 \pm 1.42$ a & $12.94 \pm 1.87 \mathrm{ab}$ & $10.72 \pm 1.85 \mathrm{~b}-\mathrm{c}$ \\
\hline Naomi/Naomi & $7.12 \pm 1.08$ а & $8.36 \pm 1.47$ a & $15.38 \pm 2.42$ b & $11.04 \pm 1.29 \mathrm{bc}$ \\
\hline Naomi & $15.28 \pm 0.98 \mathrm{c}$ & $16.35 \pm 1.88 \mathrm{de}$ & $20.57 \pm 1.06 c$ & $15.35 \pm 2.20 \mathrm{de}$ \\
\hline CV $(\%)$ & 40.30 & 42.23 & 29.09 & 35.26 \\
\hline Uygulama & \multicolumn{2}{|c|}{ ** } & \multicolumn{2}{|c|}{ ** } \\
\hline Kombinasyon & \multicolumn{2}{|c|}{ ** } & \multicolumn{2}{|c|}{ ** } \\
\hline $\begin{array}{l}\text { KombinasyonX } \\
\text { Uyqulama }\end{array}$ & \multicolumn{2}{|c|}{ ** } & \multicolumn{2}{|c|}{$* *$} \\
\hline
\end{tabular}


Renk ölçüm sonucunda tuz uygulanan bitkilerin değerlerinde artıș olduğu hue açı değerlerinde ise azalma olduğu tespit edilmiștir. Bu sonuçlara paralel olarak patlıcan kabuklarının mor renkten gri renk tonlarına doğru renk değiștirdiği belirlenmiștir. Kabuk renk tonu (hue) değerleri bakımından kontrol ve tuz uygulanan bitkiler içerisinde 'uygulamaxkombinasyon' interaksiyonları önemli bulunmuștur. Anaçlar üzerine așılama yapılması meyve rengi tonu üzerinde olumlu farklılık yaratan bir etki olup, bu etki kendi üzerine așılanan Artvin ve Naomi çeșitlerinin ikisinde de ortaya çıkmıștır (Çizelge 2).

Renk olușumu pek çok faktöre birden bağlı olarak ortaya çıkmaktadır. Bitkinin üzerindeki pozisyon ve kaçıncı meyve olduğu bile renk bakımından farklılıklara neden olabilmektedir. Bu nedenle renk ile ilgili ölçümlerin anaç seçiminde değerlendirmede ilk sıralarda yer almayacak bir parametre olduğu kanaatine varılmıștır. Borghesi vd. (2011) de, tuz stresi altında domates meyvelerinin dıș kabuk renginde belirgin düșüș olduğunu, bu düșüșlerin hassas genotiplerde daha fazla ortaya çıktığını belirtmișlerdir.

\section{Meyve suyu pH'sı bakımından ortaya çıkan değișimler}

Meyve suyunun $\mathrm{pH}$ değeri ile ilgili olarak uygulamalar arasındaki ve așı kombinasyonları arasındaki farklılık istatistiksel olarak $\mathrm{p} \leq 0.01$ düzeyinde önemlilik gösterdiği gibi, bu özellik bakımından 'uygulamaxkombinasyon' interaksiyonu da önemli bulunmuștur. Kontrol grubu bitkilerin meyvelerinden elde edilen

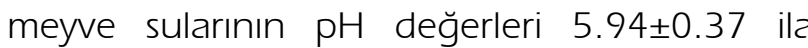
$6.41 \pm 0.34$ arasında değișmiș olup aralarında istatistiksel olarak önemli bir farklılık bulunmamıștır (Çizelge 3). Tuz uygulamasından yapılan meyve örneklerinden elde edilen $\mathrm{pH}$ değerinde azalmalar meydana gelmiș olup bu değerler arasında istatistiksel olarak farklılık ortaya çıkmıștır. En düșük pH değeri 4.67ะ0.23 ile kendi üzerine

Çizelge 3. Tuz stresi uygulaması sonunda meyve suyu pH, titre edilebilir asit (mval 100/ ml) ve TSÇKM (\%)' de ortaya çıkan değișim değerleri

Table 3. At the end of the salt stress treatment, the changed values on pH, titratable acid (mval $100 / \mathrm{ml}$ ) and TSKKM (\%) of fruit juice

\begin{tabular}{|c|c|c|c|c|c|c|}
\hline \multirow[t]{2}{*}{ Kombinasyonlar } & \multicolumn{2}{|c|}{ Meyve suyu pH } & \multicolumn{2}{|c|}{ Titre Edilebilir Asit } & \multicolumn{2}{|c|}{ TSCCKM } \\
\hline & Kontrol & Tuz & Kontrol & Tuz & Kontrol & Tuz \\
\hline Köksal/Artvin & $6.20 \pm 0.39$ а & $5.34 \pm 0.30 \mathrm{~b}-\mathrm{e}$ & $0.87 \pm 0.42$ а & $4.18 \pm 0.28 \mathrm{ef}$ & $4.33 \pm 0.23$ a & $6.05 \pm 0.40 \mathrm{~d}$ \\
\hline AGR703/Artvin & $6.10 \pm 0.60 \mathrm{a}$ & $5.46 \pm 0.75 \mathrm{de}$ & $0.83 \pm 0.36$ а & $4.37 \pm 0.32 \mathrm{e}-\mathrm{g}$ & $4.36 \pm 0.24 a$ & $6.08 \pm 0.99 \mathrm{~d}$ \\
\hline Vista/Artvin & $6.01 \pm 0.20$ a & $5.39 \pm 0.55 c-e$ & $0.72 \pm 0.60$ a & $4.23 \pm 0.39 \mathrm{e}-\mathrm{g}$ & $4.97 \pm 0.58$ a & $5.43 \pm 0.62 \mathrm{a}-\mathrm{d}$ \\
\hline Yula/Artvin & $6.04 \pm 0.39$ a & $5.45 \pm 0.48 \mathrm{de}$ & $0.89 \pm 0.39$ a & $2.60 \pm 0.35$ a & $4.09 \pm 0.62 \mathrm{a}$ & $5.62 \pm 0.38 \mathrm{~b}-\mathrm{d}$ \\
\hline Burdur/Artvin & $5.94 \pm 0.37$ a & $5.63 \pm 0.22 \mathrm{e}$ & $0.85 \pm 0.41$ a & $4.73 \pm 0.44 \mathrm{fg}$ & $4.54 \pm 0.35$ a & $5.30 \pm 0.50$ a-d \\
\hline Mardin/Artvin & $6.11 \pm 0.34$ a & $5.32 \pm 0.47$ a-e & $0.69 \pm 0.35$ a & $4.80 \pm 0.56 \mathrm{~g}$ & $4.97 \pm 0.62$ a & $5.30 \pm 0.45$ a-d \\
\hline Hawk/Artvin & $6.31 \pm 0.33$ a & $5.58 \pm 0.30 \mathrm{e}$ & $0.81 \pm 0.29$ a & $4.18 \pm 0.26 \mathrm{ef}$ & $4.82 \pm 0.79$ a & $5.32 \pm 0.69$ a-d \\
\hline Artvin/Artvin & $6.41 \pm 0.34$ a & $4.67 \pm 0.23$ а & $0.65 \pm 0.22$ а & $2.76 \pm 0.54 \mathrm{ab}$ & $4.11 \pm 0.71$ a & $4.82 \pm 0.73 \mathrm{ab}$ \\
\hline Artvin & $6.00 \pm 0.31$ a & $4.72 \pm 0.29$ a-c & $0.61 \pm 0.33$ a & $4.11 \pm 0.21 \mathrm{de}$ & $4.47 \pm 0.33$ a & $5.04 \pm 0.19$ a-c \\
\hline Köksal/Naomi & $5.97 \pm 0.65$ a & $5.59 \pm 0.21 \mathrm{e}$ & $0.85 \pm 0.39$ a & $3.95 \pm 0.17 \mathrm{de}$ & $4.42 \pm 0.38$ a & $5.91 \pm 0.71 \mathrm{~cd}$ \\
\hline AGR703/Naomi & $6.22 \pm 0.21 \mathrm{a}$ & $5.44 \pm 0.31 \mathrm{de}$ & $0.86 \pm 0.34$ а & $2.75 \pm 0.43$ ab & $4.96 \pm 0.72$ a & $5.74 \pm 0.54 \mathrm{~b}-\mathrm{d}$ \\
\hline Vista/Naomi & $6.21 \pm 0.42$ a & $5.31 \pm 0.52$ a-e & $0.84 \pm 0.35 a$ & $2.55 \pm 0.29$ a & $4.97 \pm 1.06$ a & $5.45 \pm 0.54 a-d$ \\
\hline Yula/Naomi & $6.14 \pm 0.56$ a & $5.38 \pm 0.29$ c-e & $0.81 \pm 0.34$ a & $3.29 \pm 0.50 \mathrm{bc}$ & $4.03 \pm 0.51$ a & $5.19 \pm 0.59$ a-d \\
\hline Burdur/Naomi & $6.38 \pm 0.31$ а & $5.15 \pm 0.33$ a-e & $0.76 \pm 0.36$ a & $2.79 \pm 0.23 \mathrm{ab}$ & $4.73 \pm 0.53$ a & $5.33 \pm 0.46$ a-d \\
\hline Mardin/Naomi & $6.33 \pm 0.59$ a & $5.26 \pm 0.64$ a-e & $0.68 \pm 0.26$ a & $4.44 \pm 0.33 \mathrm{e}-\mathrm{g}$ & $4.63 \pm 0.70$ a & $5.10 \pm 0.58$ a-c \\
\hline Hawk/Naomi & $6.24 \pm 0.32$ a & $5.34 \pm 0.19$ b-e & $0.78 \pm 0.28$ а & $3.55 \pm 0.30 \mathrm{~cd}$ & $4.19 \pm 0.94$ a & $5.28 \pm 0.44$ a-d \\
\hline Naomi/Naomi & $6.09 \pm 0.32$ a & $4.69 \pm 0.28$ ab & $0.67 \pm 0.32$ а & $2.97 \pm 0.35$ a-c & $4.02 \pm 0.67$ a & $4.60 \pm 0.23$ a \\
\hline Naomi & $6.17 \pm 0.16$ а & $4.84 \pm 0.31$ a-d & $0.63 \pm 0.28$ a & $3.94 \pm 0.28 \mathrm{de}$ & $4.67 \pm 0.54 a$ & $5.34 \pm 0.56$ a-d \\
\hline CV $(\%)$ & 2.29 & 5.95 & 12.11 & 21.01 & 7.56 & 7.26 \\
\hline Uygulama & \multicolumn{2}{|c|}{$\star \star$} & \multicolumn{2}{|c|}{$\star *$} & \multicolumn{2}{|c|}{$* *$} \\
\hline Kombinasyon & \multicolumn{2}{|c|}{ ** } & \multicolumn{2}{|c|}{$* *$} & \multicolumn{2}{|c|}{ ** } \\
\hline $\begin{array}{l}\text { KombinasyonX } \\
\text { Uygulama }\end{array}$ & \multicolumn{2}{|c|}{ ** } & \multicolumn{2}{|c|}{$\star *$} & \multicolumn{2}{|c|}{$* *$} \\
\hline
\end{tabular}

Aynı sütunda farklı harfi alan ortalamalar arasındaki farklıık önemlidir ( $0 \leq 0.01$ ). Ortalamalar arası farklııklar Duncan testi ile belirlenmiștir. **:

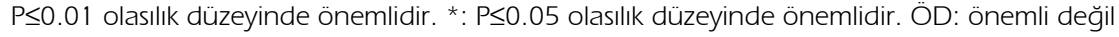


așılı Artvin/Artvin, en yüksek değer 5.63ะ0.22 ile Burdur/Artvin kombinasyonunda elde edilmiștir. Çalıșmadan elde edilen sonuçlar, önceki bazı çalıșmalarla uyumlu bulunmuștur. Krauss vd. (2006), tuzluluğun meyve suyu pH'sını belirgin bir șekilde azalttığını saptamıș olup, Colla vd. (2006) de, tuzlu koșullarda așilı kavun bitkilerinin meyvelerinde $\mathrm{pH}$ seviyesinin așısızlara göre daha düșük olduğunu belirlemișlerdir.

\section{Meyve suyunda titre edilebilir asitlik bakımından ortaya çıkan değișimler}

Kontrol bitkilerindeki titre edilebilir asit miktarı $0.61 \pm 0.33-0.89 \pm 0.39 \mathrm{mval} 100 / \mathrm{ml}$ arasında değișmiștir. Uygulamalar arasındaki ve așı kombinasyonları arasındaki farklılık istatistiksel olarak $p \leq 0.01$ düzeyinde önemlilik gösterdiği gibi, bu özellik bakımından 'uygulamaxkombinasyon' interaksiyonu da önemli bulunmuștur. Tuz uygulamaları meyvedeki asitlik miktarı değerini çok yükseltmiștir. En yüksek titre edilebilir asitlik değeri

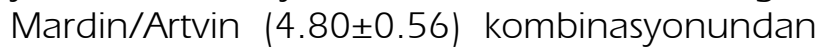
elde edilirken, en düșük değer Vista /Naomi (2.55 \pm 0.29$)$ kombinasyonunda belirlenmiștir (Cizelge 3).

Titre edilebilir asitlik meyve kalitesiyle ilișkilendirilen bir özelliktir. Krauss vd. (2006) ile Trajkova vd. (2006), bitkilerin stres altında iken topraktan su alımına devam edebilmek ve ozmotik uyumu sağlayabilmek üzere yüksek seviyede TA ve TSÇKM değerleri olușturduklarını bildirmișlerdir. Tuzluluğun TA oranını artırdığı, önceki çalıșmalarda Niedziela vd. (1993) ve Kahlaoui vd. (2011) tarafından da belirtilmektedir. Geboloğluvd. (2011), TAözelliğindeki farklııkların anaçlardan ziyade çeșitten kaynaklanan yapıda olabileceğini ifade etmektedir.

Toplam suda çözünebilir kuru madde miktarı (TSÇKM) bakımından ortaya çıkan değișimler

Kontrol bitkilerindeki TSÇKM oranı \% $4.02 \pm 0.67$ ile $4.97 \pm 1.06$ arasında değișmiștir (Çizelge 3). Uygulamalar arasındaki ve așı kombinasyonları arasındaki farklıık istatistiksel olarak $p \leq 0.01$ düzeyinde önemlilik gösterdiği gibi, bu özellik bakımından 'uygulamaxkombinasyon' interaksiyonu da önemli bulunmuștur. Tuz uygulanan bitkilerin meyvelerindeki TSÇKM oranı artmıștır. Denemede yer alan uygulamalar arasında en yüksek TSÇKM oranı AGR703/Artvin (6.08 \pm 0.99 ) ile Köksal/ Artvin (6.05 \pm 0.40$)$ ve en düșük oran Naomi/
Naomi (4.60 \pm 0.23$)$ kombinasyonlarından elde edilmiștir. Karbonhidrat biriktirme yeteneği, birçok çalıșmada tuz stresi karșısında bitkilerin ozmotik uyum sağlayabilmeleri için hayati önem tașıyan bir özellik olarak rapor edilmektedir (Eisa vd., 2012). Ünlükara vd. (2010) ayçiçeği bitkisine ait farklı dayanım seviyelerindeki genotipleri tuzlu koșullarda yetiștirmiș, stres altında șekerlerin arttığını, bu artıșların tuza tolerant genotiplerde daha fazla olduğunu belirlemișlerdir. Denemede kullanılan tüm anaç/kalem kombinasyonlarında TSÇKM miktarlarında artıș meydana gelmiștir. Turhan vd. (2009) ise, bu özelliğin anaç genotipine kuvvetli bir șekilde bağlı olarak ortaya çıktığını öne sürmektedir.

\section{Ortalama meyve ağırığı bakımından ortaya çıkan değișimler}

Uygulamalar arasındaki ve așı kombinasyonları arasındaki farklıık istatistiksel olarak $p \leq 0.01$ düzeyinde önemlilik gösterdiği gibi, bu özellik bakımından 'uygulama x kombinasyon' interaksiyonu da önemli bulunmuștur. Kontrol bitkilerinde ortalama meyve ağırlıkları 95-128 9 olarak belirlenmiș olup istatistiksel olarak uygulamalar arasındaki farklılık önemli çıkmıștır. Așılı bitkilerin meyvelerinin ağırlığı așısızlara göre farklı olduğu gibi, kalem olarak kullanılan iki çeșidin arasında da farklılıklar belirlenmiștir. Tuz uygulamaları meyve ağırlığını azaltıcı etki yapmıștır (Çizelge 4). Kontrol uygulaması ve tuz stresi altında yetiștirilen bitkilerde en düșük ve en yüksek değerler sırasıyla Artvin/Artvin kombinasyonunda $(94.99 \pm 11.08$ ile $62.00 \pm 5.74$ g) ve Vista/Naomi kombinasyonunda $(128.00 \pm 10.73$ ile $109.19 \pm 2.70$ g) aralığında elde edilmiștir. Khah vd. (2006) ve Turhan vd. (2009) de, anaç kullanımının domateste verim ve meyve özelliklerini olumlu etkilediğini rapor etmektedir. Bu durum, daha iyi su ve besin maddesi alma kapasitesine sahip anaçların pozitif etkileri olarak açıklanmaktadır. Ayrıca Bletsos vd. (2003) ve Passam vd. (2005), patlıcanda așılamanın meyve büyüklüğünü artırıcı etki yaptığını bildirmișlerdir.

\section{Ortalama meyve çapı bakımından ortaya çıkan değișimler}

Așilı veya așısız Artvin veya Naomi $F_{\text {, }}$ bitkilerinden olușan 18 farklı kombinasyona ait kontrol ve tuz uygulamasında hasat dönemindeki meyvelerin meyve çapları belirlenmiștir (Çizelge 
Çizelge 4. Tuz stresi sonunda meyve ağırlığı (g), meyve çapı (mm) ve bitki bașına toplam verim (kg) değerleri

Table 4. At the end of salt stress, fruit weight (g), fruit diameter ( $\mathrm{mm}$ ) and total yield per plant (kg) values

\begin{tabular}{|c|c|c|c|c|c|c|}
\hline \multirow{2}{*}{ Kombinasyonlar } & \multicolumn{2}{|c|}{ Meyve ağırlığı (g) } & \multicolumn{2}{|c|}{ Meyve çapı (mm) } & \multicolumn{2}{|c|}{ Bitki bașına toplam verim (kg) } \\
\hline & Kontrol & Tuz & Kontrol & Tuz & Kontrol & Tuz \\
\hline Köksal/Artvin & $109.01 \pm 5.03 a-c$ & $93.00 \pm 3.98 \mathrm{f}-\mathrm{h}$ & $46.13 \pm 7.28$ a-d & $42.70 \pm 2.79 \mathrm{bc}$ & $1.12 \pm 0.46$ a-c & $0.53 \pm 0.22 a-c$ \\
\hline AGR703/Artvin & $107.00 \pm 6.87 \mathrm{ab}$ & $93.00 \pm 3.89 \mathrm{f}-\mathrm{h}$ & $44.20 \pm 4.12 \mathrm{a}$ & $40.89 \pm 3.45 a b$ & $1.91 \pm 1.19$ a-e & $0.85 \pm 0.31 \mathrm{bc}$ \\
\hline Vista/Artvin & $110.00 \pm 6.46$ a-c & $95.00 \pm 5.09 \mathrm{~g}-\mathrm{i}$ & $45.53 \pm 5.06$ a-c & $41.93 \pm 5.67 \mathrm{bc}$ & $1.73 \pm 0.84$ a-e & $1.82 \pm 0.20 \mathrm{~d}$ \\
\hline Yula/Artvin & $106.00 \pm 29.27 \mathrm{ab}$ & $84.00 \pm 3.85 \mathrm{~d}-\mathrm{f}$ & $47.43 \pm 3.19$ a-f & $43.45 \pm 3.27 \mathrm{~b}-\mathrm{d}$ & $1.91 \pm 0.83$ a-e & $0.94 \pm 0.27 c$ \\
\hline Burdur/Artvin & $98.00 \pm 4.77$ а & $82.00 \pm 4.86$ c-e & $45.11 \pm 2.47 \mathrm{ab}$ & $41.86 \pm 2.95$ a-c & $1.26 \pm 0.73$ a-d & $0.58 \pm 0.27$ a-c \\
\hline Mardin/Artvin & $99.00 \pm 6.90 \mathrm{a}$ & $74.00 \pm 7.38 \mathrm{bc}$ & $46.78 \pm 8.41$ a-e & $42.34 \pm 3.95 \mathrm{bc}$ & $1.14 \pm 0.68$ a-d & $0.71 \pm 0.39$ a-c \\
\hline Hawk/Artvin & $105.00 \pm 7.09 a b$ & $87.00 \pm 4.71 \mathrm{e}-\mathrm{g}$ & $47.65 \pm 4.77 \mathrm{a}-\mathrm{g}$ & $43.50 \pm 2.91 \mathrm{~b}-\mathrm{d}$ & $1.15 \pm 0.69$ a-d & $0.50 \pm 0.28$ a-c \\
\hline Artvin/Artvin & $94.99 \pm 11.08$ a & $62.00 \pm 5.74 a$ & $44.45 \pm 3.68 a$ & $38.14 \pm 2.93 \mathrm{ab}$ & $0.97 \pm 0.21 \mathrm{ab}$ & $0.38 \pm 0.13 a b$ \\
\hline Artvin & $97.00 \pm 6.49$ a & $65.00 \pm 6.23 a b$ & $44.56 \pm 3.55 a$ & $36.36 \pm 3.45$ a & $0.73 \pm 0.29$ a & $0.18 \pm 0.07$ a \\
\hline Köksal/Naomi & $125.00 \pm 5.48 \mathrm{~cd}$ & $105.00 \pm 7.02 \mathrm{jk}$ & $54.77 \pm 2.68 \mathrm{~g}$ & $50.66 \pm 3.13 \mathrm{e}$ & $2.41 \pm 1.13 \mathrm{de}$ & $0.78 \pm 0.28 \mathrm{bc}$ \\
\hline AGR703/Naomi & $120.00 \pm 6.42 \mathrm{~b}-\mathrm{d}$ & $105.24 \pm 3.49 \mathrm{jk}$ & $54.43 \pm 1.67 \mathrm{fg}$ & $50.13 \pm 2.74 \mathrm{e}$ & $2.62 \pm 0.97 \mathrm{e}$ & $1.00 \pm 0.38 c$ \\
\hline Vista/Naomi & $128.00 \pm 10.73 d$ & $109.19 \pm 2.70 \mathrm{k}$ & $53.78 \pm 3.16 \mathrm{e}-\mathrm{g}$ & & $2.12 \pm 0$. & $0.83 \pm 0.43 \mathrm{bc}$ \\
\hline Yula/Naomi & $121.00 \pm 8.58 \mathrm{~b}-\mathrm{d}$ & $101.40 \pm 6.96 \mathrm{~h}-\mathrm{k}$ & $53.32 \pm 1.69 \mathrm{~d}-\mathrm{g}$ & $48.68 \pm 2.74 \mathrm{de}$ & $2.02 \pm 0.85$ b-e & $0.91 \pm 0.44 \mathrm{c}$ \\
\hline Burdur/Naomi & $124.00 \pm 3.70 \mathrm{~cd}$ & $98.70 \pm 7.69$ h-j & $52.21 \pm 4.46 \mathrm{~b}-\mathrm{g}$ & $48.40 \pm 2.89 \mathrm{de}$ & $1.82 \pm 0.89$ a-e & $1.81 \pm 0.48 d$ \\
\hline Mardin/Naomi & $119.00 \pm 5.33 \mathrm{~b}-\mathrm{d}$ & $84.61 \pm 6.14 \mathrm{~d}-\mathrm{f}$ & $52.72 \pm 3.19 \mathrm{c}-9$ & $47.18 \pm 2.08$ c-e & $2.05 \pm 0.69$ b-e & $0.84 \pm 0.39 \mathrm{bc}$ \\
\hline Hawk/Naomi & $124.00 \pm 6.57 \mathrm{~cd}$ & $103.04 \pm 6.76 \mathrm{i}-\mathrm{k}$ & $53.54 \pm 4.07 \mathrm{e}-\mathrm{g}$ & $49.04 \pm 3.13 \mathrm{e}$ & $2.34 \pm 0.49$ c-e & $0.81 \pm 0.33 b c$ \\
\hline Naomi/Naomi & $118.00 \pm 7.35 \mathrm{~b}-\mathrm{d}$ & $78.71 \pm 6.90 \mathrm{c}-\mathrm{e}$ & $51.12 \pm 3.93 \mathrm{a}-\mathrm{g}$ & $42.17 \pm 2.82 \mathrm{bc}$ & $1.09 \pm 0.49$ a-c & $0.37 \pm 0.21 \mathrm{ab}$ \\
\hline Naomi & $120.00 \pm 13.07 \mathrm{~b}-\mathrm{d}$ & $76.08 \pm 3.62 \mathrm{~cd}$ & $52.05 \pm 4.49 \mathrm{~b}-\mathrm{g}$ & $40.91 \pm 3.82 \mathrm{ab}$ & $0.99 \pm 0.55 \mathrm{ab}$ & $0.37 \pm 0.28$ ab \\
\hline CV $(\%)$ & 9.65 & 15.80 & 8.03 & 9.76 & 35.38 & 55.47 \\
\hline & \multicolumn{2}{|c|}{ ** } & \multicolumn{2}{|c|}{$* *$} & \multicolumn{2}{|c|}{ ** } \\
\hline Kombinasyon & \multicolumn{2}{|c|}{ ** } & \multicolumn{2}{|c|}{$\star \star$} & \multicolumn{2}{|c|}{ ** } \\
\hline $\begin{array}{l}\text { KombinasyonX } \\
\text { Uygulama }\end{array}$ & \multicolumn{2}{|c|}{ ** } & \multicolumn{2}{|c|}{ ÖD } & \multicolumn{2}{|c|}{ ** } \\
\hline
\end{tabular}

Aynı sütunda farklı harfi alan ortalamalar arasındaki farklıık önemlidir ( $\rho \leq 0.01$ ). Ortalamalar arası farklılıklar Duncan testi ile belirlenmiștir.

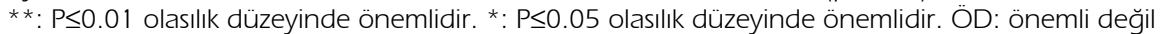

4). Uygulamalar arasındaki ve așı kombinasyonları arasındaki farklılık istatistiksel olarak $\mathrm{p} \leq 0.01$ düzeyinde önemlilik göstermiștir. Kontrol bitkilerindeki meyve çapları 44.20 ile 54.77 $\mathrm{mm}$ arasında değișmiștir ve istatistiksel olarak uygulamalar arasında farklılık önemli bulunmuștur.

Tuz uygulanan bitkilerin meyvelerindeki meyve çapları azalmıștır. Denemede yer alan uygulamalar arasında en yüksek meyve çapı değeri Köksal/ Naomi (50.66 $3.13 \mathrm{~mm})$ kombinasyonundan, en düșük olanı ise Artvin $(36.36 \pm 3.45 \mathrm{~mm})$ genotipinden elde edilmiștir. Davis vd. (2008), bitkilerdeki meyve büyüklüğü, verim ve kalite parametrelerinin kalemin genotipi ve cevre koșullarından etkilendiğini, fakat anaçların da bitki büyümesi ve kalite parametreleri üzerinde etki sahibi olduğunu bildirmektedir. Patlıcanda anaç kullanımının performans üzerindeki etkilerini inceleyen Gisbert vd. (2011), așılamanın meyve uzunluğunu, genișliğini ve meyve indeksini artırdığını belirlemișlerdir. Benzer sonuçları tespit eden Aloni vd. (2010) bu durumun, anaç vigorunun yüksekliği ve anaçta olușan hormonların etkisinden kaynaklandığını ileri sürmektedir.

\section{Bitki bașına toplam verim bakımından ortaya çıkan değișimler}

Yetiștirme dönemi boyunca beș haftasını dolduran meyveler toplanarak tartılmıș ve toplam bitki bașına verim hesaplanmıș ve elde edilen değerler Çizelge 4'de verilmiștir. 18 farklı kombinasyon içerisinde ortalama bitki bașına verim bakımından en yüksek değerler Naomi’nin yer aldığı uygulamalardan elde edilmiștir. Uygulamalar arasındaki ve așı kombinasyonları arasındaki farklılık istatistiksel olarak $\mathrm{p} \leq 0.01$ düzeyinde önemlilik gösterdiği gibi, bu özellik bakımından 'uygulama x kombinasyon' interaksiyonu da önemli bulunmuștur.

Kontrol bitkileri içinde enyüksekverimAGR703/ Naomi (2.62 $\pm 0.97 \mathrm{~kg})$ kombinasyonundan elde edilirken en düșük Artvin $(0.73 \pm 0.29 \mathrm{~kg})$ genotipinden elde edilmiștir. Tuzlu koșullarda en yüksek verim Vista/Artvin $(1.82 \pm 0.20 \mathrm{~kg})$ kombinasyonundan elde edilirken en düșük 
Artvin $(0.18 \pm 0.07 \mathrm{~kg})$ genotipinde bulunmustur. Her kombinasyonunun kendi kontrolü ile karșılaștırılması sonucunda elde edilen \% değișim veya oransal değișim, kombinasyonların performansını ortaya koyması nedeniyle kullanılmaktadır. Tuz uygulaması sonucu en düșük değeri veren Artvin genotipi yaklașık \%24.7 oranında verim kaybına uğrarken, en yüksek verimin elde edildiği Vista/Artvin genotipi \%5.2 oranında değer artıșı göstermiștir. Kontrolde en yüksek değerin elde edildiği AGR703/ Naomi kombinasyonunda tuzlu koșullara \%38.2 oranında verim kaybı görülmüștür. Wan vd. (2010), hıyarda tuz stresinin verimi azalttığını, her bir birim AC artıșının \%5.7 oranında verim kaybı olușturduğunu belirlemișlerdir. Verim kaybının bileșenleri olarak meyve ağırlığı ve meyve sayısındaki düșüșler gösterilmektedir. Patlıcanda tuzlu sulama suyu ile sulanan bitkilerde meyve verimi, meyve ağırlığı ve sayısındaki azalmalar nedeniyle olumsuz etkilenmiștir (Ünlükara vd., 2010). Așılı bitki kullanımı tekniğinin tuzlu koșullarda verimi artırdığı Rivero vd. (2003) tarafından kanıtlanmıștır. Anaçların kuvvetli (vigor) kök sistemlerinin daha iyi su ve besin maddesi alabilmesi sayesinde verim kaybının așılı bitkilerde daha az ortaya çıtığı Ruiz vd. (1997) tarafından da belirtilmektedir.

\section{SONUC̣LAR}

Kullanılan 18 adet anaç/kalem kombinasyona ait patıcan bitkilerinin tuz stresine karșı gösterdiği performanslar farklı olmuștur. İncelenen değerler

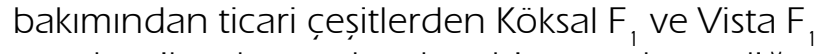
anaçları ile olușturulan kombinasyonların diğer kombinasyonlara göre daha iyi sonuçlar verdiği ve bitkinin tuz toleransını artırdığı belirlenmiștir. Bununla birlikte anaç olarak kullanılan Burdur ıslah hattı, ticari anaçlarla tuz toleransı bakımından rekabet edebilir nitelikte bulunmuș ve bu genotipin türler arası melezlemelerde kullanılması, biotik stres faktörleri belirlenerek hastalıklara dayanım kazandırıması gibi çalıșmaların yapılması yoluyla anaç geliștirme programlarına dahil edilebileceği belirlenmiștir.

\section{KAYNAKLAR}

Aktas H, Daler S, Ozen O, Gencer K, Bayindir D, Erdar I (2013). The effect of some growing substrate media on yield and fruit quality of eggplant grown and irrigated by drip irrigation system in greenhouse. Infrastruktura I Ekologia Terenów Wiejskich Infrastructure and Ecology of Rural Areas $\mathrm{Nr}$ 1/lı/2013, Polska Akademia Nauk, Oddział w Krakowie, pp. 5-11.
Aloni B, Cohen R, Karni L, Aktas H, Edelstein M (2010). Hormonal signaling in rootstock-scion interactions. Scientia Horticulturae, 127: 119-126.

Altunlu $\mathrm{H}$ (2011). Așllamanın domateste kuraklık stresine etkileri. The effect of graftıng against drought stress in tomatoes. Doktora tezi. Ege Universitesi Fen Bilimleri Enstitüsü, İzmir.

TUIK (2017), Turkish Statistical Institute, (www.tuik.gov. tr), Access date: 6.11.2017.

Bletsos F, Thanassoulopoulos C, Roupakias D (2003). Effect of grafting on growth, yield and Verticillium wilt of eggplant. HortScience, 38:183-186.

Borghesi E, Gonzalez-Miret ML, Escudes-Martinez A (2011). Effects of salinity stress on carotenoids, anthocyanins, and color of diverse tomato genotypes. Journal of Agricultural and Food Chemistry, 59(21): 11676-82.

Boyacı Cl (2008). Bilinmeyen yönleri ile patlıcan. Meyve ve Sebze Dünyası, 1(7): 56-57.

Colla G, Rouphael Y, Cadarelli M, Rea, E (2006). Effect of salinity on yield, fruit quality, leaf gas exchange, and mineral composition of grafted watermelon plants. HortScience., 41 (3): 622-627.

Colla G, Rouphae, Y, Leonardi C, Bie Z (2010). Role of grafting in vegetable crops grown under saline conditions. Scientia Horticulturae, 127: 147-155.

Cürük S, Dasgan HY, Mansuroglu S, Kurt S, Mazmanoglu M, Tarla G, Durgac C (2010). Leaf mineral composition of grafted eggplant grown in soil infested with Verticillium and root-knot nematods. Pesquisa Agropecuária Brasileira, 45(8): 879-885.

Daunay M, Janick J (2007). History and iconography of eggplant. Chronica Horticulture. 47(3): 16-22.

Davis AR, Perkins-Veazie P, Hassell R, Levi A, King SR, Zhang $X$ (2008). Grafting effects on vegetable quality, HortScience. 43(6).

Eisa S, Hussin S, Geissler N. ve Koyro, HW (2012). Effect of $\mathrm{NaCl}$ salinity on water relations, photosynthesis and chemical composition of quinoa (Chenopodium quinea Wild.) as a potential cash crop halophyte. AJCS, 6(2): 357368.

Estan MT, Martinez-Rodriguez MM, Perez-Alfocea F, Flowers TJ, Bolarin MC (2005). Grafting raises the salt tolerance of tomato through limiting the transport of sodium and chloride to the shoot. Journal of Experimental Botany, 56(412): 703-712.

Fernandez-Garcia N, Cerda A, Carvajal M (2003). Grafting, a useful technique for improving salinity tolerance of tomato? Acta Horticultural, 609: 251-256.

Geboloğlu N, Yılmaz E, Çakmak P, Aydın M, Kasap $Y$ (2011). Determining of the yield, quality and nutrient content of tomatoes grafted on different rootstocks in soilless culture. - Scientific Research and Essays, 6(10): 2147-2153

Gisbert C, Prohens J, Nuez F (2011). Performance of eggplant grafted onto cultivated, wild, and hybrid materials of eggplant and tomato. International Journal of Plant Production, 5(4): 367-38. 
Hossain MM, Nonami H (2012). Effect of salt stress on physiological response of tomato fruit grown in hydroponic culture system. Horticultural Science (Prague), 39(1): 26-32.

Kahlaoui B, Hachicha M, Rejeb S, Rejeb MN, Hanchi $B$, Misle $E$ (2011). Effect of saline water on tomato under subsurface drip irrigation: Nutritional and foliar aspects, Journal of Soil Science and Plant Nutrition, 11(1): 69 - 86.

Karaçalı i (1993). Bahçe Ürünlerinin Muhafazası ve Pazarlanması. EÜZF Yayınları, No: 494, P.444.

Khah EM, Kakava E, Mavromatis A, Chachalis D, Goulas $C$ (2006). Effect of grafting on growth and yield of tomato (Lycopersicon esculentum Mill.) in greenhouse and openfield. Journal of Applied Horticulture, 8: 3-7.

King SR, Davis AR, Zhang X, Crosby K (2010). Genetics, breeding and selection of rootstocks for Solanaceae and Cucurbitaceae. Scientia Horticulturae, 127: 106-111.

Krauss S, Schnitzler W, Grassmann J, Woltike M (2006). The influence of different electrical conductivity values in a simplified recirculating soilless system on inner and outer fruit quality characteristics of tomato. Journal of Agricultural and Food Chemistry, 54: 441-448.

Kușvuran Ș, Dașgan HY, Abak K (2011). Responses of different melon genotypes to drought stress. Yuzuncu Yıl University Journal of Agricultural Sciences, 21: 209-219.

Libia I, Trejo-Téllez Fernando C. Gómez-Merino (2012). Nutrient Solutions for Hydroponic Systems, Hydroponics - A Standard Methodology for Plant Biological Researches, Dr. Toshiki Asao (Ed.), ISBN: 978- 953-51-0386-8, InTech, Available from: http://www.intechopen.com/books/ hydroponics-a-standardmethodology-for-plant-biologicalresearches/nutrient-solutions-for-hydroponic-systems

Niedziela Jr CE, Nelson PV, Willits DH, Peel MM (1993). Short-tenn salt-shock effects on tomato fruit quality, yield, and vegetative prediction of subsequent fruit quality. American Society for Horticultural Science, 118:12-16.

Oztekin GB, Tuzel Y (2011). Salinity response of some tomato rootstocks at seedling stage. African Journal of Agricultural Research, 6(20): 4726-4735.

Passam HC, Stylianoy M, Kotsiras A (2005). Performance of eggplant grafted on tomato and eggplant rootstocks. European Journal of Horticultural Science, 70: 130-134.

Rivero RM, Ruiz JM, Sanchez E, Romero L (2003). Does grafting provide tomato plants an advantage against $\mathrm{H} 2 \mathrm{O} 2$ production under conditions of thermal shock. Physiologia Plantarum, 117: 44-50

Romero-Aranda MR, Soria T, Cuartero J (2001). Tomato plant-water uptake and plant-water relationships under saline growth conditions. Plant Science, 160(2): 265-272.
Ruiz JM, Belakbir A, López-Cantarero I, Romero L (1997). Leaf-macronutrient content and yield in grafted, melon plants. A model to evaluate the influence of rootstock genotype. Scientia Horticulturae, 71:227-234.

Sangtarashani ES, Tabatabaei SJ, Bolandnazar S (2013). Yield, Photosynthetic efficiency and Quality parameters of Cherry tomato as affected by $\mathrm{Ca} 2+$ and $\mathrm{K}+$ under $\mathrm{NaCl}$ salinity. , 5(12): 1280-1288.

Savvas D, Colla G, Rouphael Y, Schwarz D (2010). Amelioration of heavy metal and nutrient stress in fruit vegetables by grafting. Scientia Horticulturae, 127: 156-161.

Sivritepe N, Sivritepe HO, Celik H, Katkat AV (2010). Salinity responses of grafted grapevines: Effects of scion and rootstock genotypes. Notulae Botanicae Horti Agrobotanici Cluj-Napoca, 38(3): 193-201.

Sönmez K (2014). Likopen, ß-Karoten and Morfolojik Özellikler Bakımından Yerel Sofralık Domateslerde Genotip X Çevre İnteraksiyonu. Doktora tezi, Ankara Üniversitesi, Fen Bilimleri Enstitüsü, Ankara.

Trajkova F, Papadantonakis N, Savvas D (2006). Comparative effects of $\mathrm{NaCl}$ and $\mathrm{CaCl} 2$ salinity on cucumber grown in a closed hydroponic system. HortScience, 41 : 437441.

Tümbilen Y, Frary A, Mutlu S, Doganlar S (2011). Genetic diversity in Turkish eggplant (Solanum melongena) varieties as determined by morphological and molecular analysis. International Research Journal of Biotechnology, 2(1): 16-25.

Turhan A, Seniz V, Kuscu H (2009). Genotypic variation in the response of tomato to salinity. African Journal of Biotechnology,8(6): 1062-1068.

Ünlükara A, Kurunc A, Duygukesmez G, Yurtseven E, Suarez DL (2010). Effects of salinity on eggplant (Solanum melongena L.) growth and evapotranspiration. Irrigation and Drainage, 59: 203-214.

Wan S, Kang Y, Wang D, Liu SP (2010). Effect of saline water on cucumber (Cucumis sativus L.) yield and water use under drip irrigation in North China. Agriculture water management. Doi: 10.1016/J.agwat.2010.08.003.

Yașar F (2003). Tuz stresi altındaki patlıcan genotiplerinde bazı Antioksidant enzim aktivitelerinin in vitro ve in vivo olarak incelenmesi. Doktora tezi, Yüzüncü Yıl Üniversitesi Fen Bilimleri, Van.

Yașar F, İhtiyaroğlu S, Uzal Ö, Ellialtıŏlu Ș (2011). Karpuzda (Citrullus lanatus (Thunb.) Mansf.) Tuza Tolerans Özelliği ile Tohum İriliği ve Kotiledon Yaprağı Arasındaki İlișkinin İncelenmesi. Vı. Ulusal Bahçe Bitkileri Kongresi, 4-8 Ekim, Șanlıurfa. 


\title{
İçme Suyu Kaynaklarında Hidrodinamik Kavitasyon Yöntemi İle Mikrobiyal Kirlilik Giderimi
}

\author{
Efsun DINDAR \\ Uludağ Üniversitesi, Mühendislik Fakültesi, Çevre Mühendisliği Bölümü, Bursa
}

Sorumlu yazar e-mail (Corresponding author e-mail): efsun@uludag.edu.tr

Geliș tarihi (Received) : 27.12.2018

Kabul tarihi (Accepted): 05.03.2019

DOI : $10.21657 /$ topraksu.544670

\section{Öz}

Bu çalıșmada, içme suyu olarak kullanılan ham su, orifis bazlı bir hidrodinamik kavitasyon cihazı ile laboratuvar ölçeğinde mekanik olarak kavite edilmiștir. Hidrodinamik kavitasyon seti 25 L'ik bir tank ve 1,5 kW'Iık pozitif yer değiștirme pompasında olușan bir cihazdır. Cihazda $3 \mathrm{~mm}$ çapında tek delikli orifis plaka kullanıımıștır. Sistemin ana hattının çapı 19 mm olup hava girișini önlemek için deșarj borusu tanktaki sıvı seviyesinin altına yerleștirilmiștir. Hidrodinamik kavitasyon çalıșması 150 dk yürütülmüș olup 0, 30, 60, 90, 120, ve 150. dk'larda tanktan numune alınmıștır. Optimum kavitasyon zamanı 5 bar basınçta 60-90 dk arasında bulunmuștur. Sonuçlar incelendiğinde, $90 \mathrm{dk}$ sonunda \%94-\%100 (1,23 log) arasında bakteriyel giderimin gerçekleștiği görülmüștür. Çalıșma verileri, hidrodinamik kavitasyonun hücre parçalayarak bakteri aktifliğini azaltmada etkili olduğunu ortaya koymuștur. İçilebilir nitelikteki suların mikrobiyal dezenfeksiyonu için hidrodinamik kavitasyon etkili bir șekilde kullanılabilir bir sistemdir.

Anahtar Kelimeler: Bakteri, dezenfeksiyon, hidrodinamik kavitasyon, içme suyu, toplam bakteri sayısı.

\section{Microbial Removal of Drinking Water Resources by Hydrodynamic Cavitation Method}

\begin{abstract}
The effect of hydrodynamic cavitation $(\mathrm{HC})$ on the removal of microorganisms in potable water were investigated using a laboratory scale device. The hydrodynamic cavitation setup consisted of a $25 \mathrm{~L}$ tank, a positive displacement pump $(1.5 \mathrm{~kW})$, and a cavitation device. Single-hole orifice plates with diameters of $3 \mathrm{~mm}$ was used as cavitation devices. The diameter of the main line was $19 \mathrm{~mm}$, and the discharge well was placed below the liquid level in the tank to avoid introducing air. Hydrodynamic cavitation experiments were run for $150 \mathrm{~min}$, and the samples were collected from the tank at 0,30 , $60,90,120$, and $150 \mathrm{~min}$. The optimal cavitation time was 60-90 min with a pump pressure of 5 bar. Results showed that after 90 min of cavitation, bacterial removal percentages of $94 \%$ to $100 \%(\log 1.23)$ were obtained. Experiments showed that hydrodynamic cavitationis very effective in reducing bacterial ability. Hydrodynamic cavitation can be effectively used for the microbial disinfection of potable water.
\end{abstract}

Key word: Bacteria, disinfection, hydrodynamic cavitation, potable water, total bacteria count

\section{GíRiș}

İçme suyu kalitesi günümüzde oldukça önemli bir konudur. Son yıllarda endüstriyel kirlilikler, tarımsal faaliyetler ve nüfus artıșına bağlı

olarak çoğalan evsel atıklardan dolayı içilebilir nitelikteki suların kalitesi düșmektedir. Bu durum patojen mikroorganizmaların çoğalmasına 
neden olarak sudan bulașan ölümcül olabilen hastalıkların ortaya çıkmasına sebep olmaktadır. Kirliliğin kontrol edilmesi veya etkili arıtma yöntemlerinin kullanılmasıyla içme suyu kalitesi iyileștirilebilmektedir.

Kimyasal, fiziksel ve biyolojik kirliliklerin giderilmesi için çeșitli arıtma yöntemleri kullanılmaktadır. Hastalık yapıcı mikroorganizmaların sebep olduğu biyolojik kirliliği gidermek için dezenfeksiyon ișlemi yapılmaktadır. Dezenfeksiyonun amacı insan sağlığı açısından riskli olan mikroorganizmaları ortadan kaldırmaktır. Uzun yıllardır suların dezenfeksiyonun da çeșitli kimyasal ve fiziksel yöntemler uygulanmaktadır. Klorlama, ozonlama ve ultraviyole ıșığı gibi içilebilir su dezenfeksiyonu için rutin olarak çeșitli fiziksel ve kimyasal teknikler kullanılmaktadır (Haas vd., 1990; Labatiuk vd., 1992; Giese ve Darby, 2000). Ancak kimyasal dezenfeksiyon teknikleri, kanserojen yan ürünlerin olușumu gibi dezavantajlara sahip olabilmektedir. Bu nedenle, bazı yöntemlerin dezavantajları, etkinliklerinden daha fazla olduğu için alternatif bașka tekniklerin geliștirilmesine intiyaç duyulmaktadır.

Su arıtımında yeni yöntemlerin araștırılması için hala birçok faaliyet alanı bulunmaktadır. Kavitasyon prosesi de bu alanlardan biri olarak görülmektedir. Kavitasyon, bir sıvı içinde mikro kabarcıkların olușumu, büyümesi ve çökmesi olarak bilinmektedir (Jyoti ve Pandit, 2001). Sivı, zaman içinde ve mesafe boyunca basınç alanında değișimlere maruz kaldığında, baloncukların olușmasına neden olur. Bu baloncuklar hem sıvıdan gelen buharla hem de sıvıdaki çözünmüș gazlarla dolar ve sonra șiddetli sıkıșma ile içeriye doğru patlar. Hidrodinamik kavitasyon, bir orifis, vana ya da ventüri gibi dar bir geçitten sıvının geçmesi ile olușturulmaktadır.

Arrojo vd., (2008) yaptıkları çalıșmada, E. coli konsantrasyonu arttıkça orifis plakasında hız sabiti orta derecede azaldığını, ventüri tipi uygulamada ise aynı kaldığını bulmușlardır. Orifis plakalarda, dezenfeksiyonun bir kısmı OH radikali üretimi ile ilișkilidir ve bu nedenle, E. coli konsantrasyonu arttıkça, radikal konsantrasyonu sınırlayıcı etki göstermektedir. Diğer yandan ventüri tipi tasarımın etkilenmesinin sebebi, reaktantın sınırlayıcı olmaması dolayısıyla bakterilerin mekanik bozulmasının süreçte önemli bir rol oynaması olarak açıklanmaktadır.
Jyoti ve Pandit (2001) yaptıkları çalıșma sonucunda hidrodinamik kavitasyonun içme suyu üretimi için potansiyel bir fiziki su dezenfeksiyon tekniği olduğunu bulmușlardır. Save vd. (1994) özellikle hücre bozulmasında hidrodinamik kavitasyonun etkili olduğunu ortaya koymușlardır. Balasundaram ve Harrison (2006) yaptıkları çalıșmada orifis plaka kullanarak E.colínin parçalanmasını sağlayarak hücre içi proteinlerin organizmadan serbest bırakıldığını bulmușlardır.

Hidrodinamik kavitasyon ile E.coli için yüksek deaktivasyon elde edildiği yapılan çalıșmalarla belirlenmiștir (Arrojo vd., 2008; Mezule vd., 2009). Li vd. (2016) hidrodinamik kavitasyon prosesinin ürettiği serbest radikaller ile membran lipitleri dahil olmak üzere hücresel bileșenlerin zarar gördüğünü tespit etmișlerdir. Hidrodinamik kavitasyonun dezenfeksiyon etkisi, aynı anda hareket eden mekanizmaların kombinasyonu olarak açıklanmaktadır (Mason vd., 2003).

-Mekanik etkiler: Türbülans üretimi, SIVı sirkülasyon akımları ve makaslama gerilmeleri.

-Kimyasal etkiler: Aktif serbest radikallerin olușması.

-Isı etkileri: Lokal sıcak noktaların üretimi (çok yüksek sıcaklık ve basıncın lokal olarak durumu).

Bu bağlamda çalıșmanın amacı, içme suyu amaçlı su dezenfeksiyonunda alternatif bir metot olarak hidrodinamik kavitasyon sisteminin, mikrobiyal giderim üzerine etkisini ortaya koymaktır. Çalıșma kapsamında, kimyasal madde ilavesi olmadan su dezenfeksiyonunda hidrodinamik kavitasyonun kullanılabilirliğini araștırılmıștır. İçme suyunda kirlilik göstergesi olarak görülen spesifik mikroorganizmalar (Clostridium perfiringens, Enterekok, Escherichia Coli, Pseudomonas aeruginosa, Toplam Bakteri Sayısı, Toplam Koliform) seçilerek çalıșma yapılmıștır.

\section{MATERYAL VE YÖNTEM}

\section{Materyal}

Bu çalıșmada kullanılan su, Bursa'da bulunan, Bursa Büyükșehir Belediyesi, BUSKi Genel Müdürlüğü bünyesindeki Dobruca İçme Suyu Arıtma Tesisi girișinden alınmıștır. Su, Doğancı Barajından $\varnothing 1600 \mathrm{~mm}$ çapında, (3300 mt.) uzunluğunda çelik boru ile alınarak, tesise gelmektedir. Çalıșma kapsamında kullanılan su özellikleri Tablo 1'de verilmiștir. 
Çizelge 1. Calıșmada kullanılan içilebilir suyun özellikleri Table 1. Microbial characterization of potable water used in the study

\begin{tabular}{lc}
\hline Parametre & Değer \\
\hline Clostridium perfiringens (MF) CFU/100 ml & 1 \\
Enterekok CFU/100 ml & 1 \\
Escherichia Coli (E.coli ) CFU/100 ml & 1 \\
Pseudomonas aeruginosa CFU/100 ml & 40 \\
Toplam Bakteri Sayısı (22 ${ }^{\circ} \mathrm{C}$ ) CFU/1 ml & $>200$ \\
Toplam Koliform CFU/100 ml & 107 \\
\hline
\end{tabular}

\section{Çalıșmada Kullanılan Hidrodinamik Kavitasyon Sistemi}

Arıtma çamurlarının hidrodinamik kavitasyon denemeleri orifis plakalı kavitasyon cihazı ile yürütülmüștür. Kullanılan sistem 20 It hacminde paslanmaz çelikten yapılmıș bir reaktör, 1,5 kw motor gücüne sahip dikey milli santrifüj pompa ve kavitasyonun gerçekleștiği orifis kısmından olușmaktadır (Șekil 1). Pompanın deșarj kısmına bağlı olan boru ana hat ve bypass hattı olmaküzere dallanmaktadır. Ana hat üzerine takılan farklı delik çaplarına sahip orifis plakaları farklı yoğunluklarda ve özelliklerde kavitasyon olușumunu mümkün kılmaktadır. Bir orifis plakası, hatta boru flanșları arasına yerleștirilerek akıș hızının artmasına ve basıncın azalmasına neden olur. Orifis plakalarının kullanıldığı hidrodinamik kavitasyon sistemlerinde delik çaplarının genellikle 5 mm'den küçük olduğu literatürden bilinmektedir (Chanda, 2012; Gogate ve Pandit, 2000). Çalıșma kapsamında denenecek orifis plakanın delik çapı literatürle uyumlu olarak $3 \mathrm{~mm}$ olarak seçilmiștir. Sistem 5 bar basıncında çalıșmıștır.

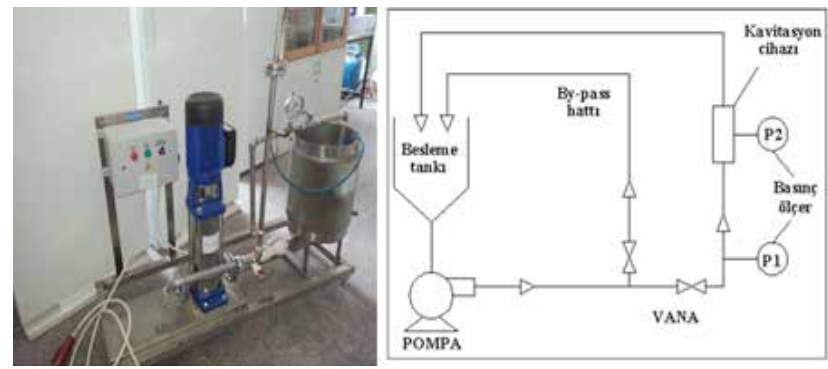

Șekil 1. Çalıșmada kullanılan hidrodinamik kavitasyon sistemi Figure 1. Hydrodynamic cavitation system used in operation

\section{Kavitasyon sayısının (Ks)hesabı}

Kavitasyon sayısı, Cv olarak bilinen boyutsuz bir sayıdır ve kavitasyon yoğunluğu ile debi șartlarını ilișkilendirmek için kullanılmaktadır. İdeal șartlarda kavitasyon, $\mathrm{C} v<1$ olduğunda olușmaktadır. Kavitasyon sayısı Eșitlik 1'de verilen formülle hesaplanmaktadır (Gogate ve Pandit, 2000).

$C_{V}=\left(P_{2}-P_{v}\right) /\left(0,5^{*} P^{*} V^{2}{ }_{\text {th }}\right) \quad($ Eș. 1$)$

Yukarıdaki denklemde $P_{2}$ tamamen geri kazanılan așağı akım basıncını, Pv sıvının buhar basıncını ve Vth daralma bölgesindeki sıvı hızını ifade etmektedir.

Ks hesabı için kavitasyon ișlemi bașlatılmadan önce kavitasyon hücresindeki çamur örneğinin 3 L'sinin boș bir kabı kaç saniyede doldurduğu tespit edilmiștir. Bulunan sonuç 17 saniyedir. Yapılan matematiksel hesaplar așağıda sıralanmıștır:

$-0,176 \mathrm{~L} / \mathrm{sn}=1,764 * 10^{-4} \mathrm{~m}^{3} / \mathrm{sn}=\mathrm{O}$ (Debi)

$-A=\frac{\pi}{4} d^{2}$ (orifisin yarıçapı $1,5 \mathrm{~mm}^{\prime} \mathrm{dir}$ ). $A=7,065^{*} 10^{-6}$ $\mathrm{m}^{2}$ (Alan)

$-V$ th $=Q / A \rightarrow\left(1,764 * 10-4 \mathrm{~m}^{3} / \mathrm{sn}\right) /\left(7,065^{*} 10^{-6}\right.$

$\left.\mathrm{m}^{2}\right)=24,98 \mathrm{~m} / \mathrm{sn}(\mathrm{HIz})$

-101325 (açık hava basıncı) - 3500 (suyun buhar

basıncı) $=97825$ bar

$-C_{v}=\left(P_{2}-P_{v}\right) /\left(0,5^{*} P^{*} V^{2}{ }_{\text {th }}\right)$

$-C_{V}=(101325-3500) /(0,5 * 1000 * 24,982)=0,31$

olarak hesaplanmaktadır.

\section{Kavitasyon Süresince İzlenen Mikrobiyolojik Parametreler}

Kavite edilen su numunesinden kavitasyonun 0., 30., 60., 90., 120. ve 150. dakikalarında örnekler alınmıș ve tüm örneklerde Toplam Canlı Sayısı, E.Coli, Toplam Koliform, Enterokok, Clostridium Perfingers, Pseudomonas aeruginosa analizleri yapıımıștır.

\section{Mikrobiyolojik Analizlerde Kullanılan Yöntemler}

Pseudomonas aeruginosa'nın tespiti ve sayımı Membran Filtrasyon yöntemi ile TS EN ISO 16266:2006standartınagöreyapılımıștır. Membran filtre sisteminden numune suyu süzülerek seçici besiyerine (CN Agar) yerleștirilmiș ve $(36 \pm 2)^{\circ} \mathrm{C}^{\prime} \mathrm{de}$ $48 \pm 4$ saat sonunda olușan koloniler sayılmıștır. Doğrulama için Asetamit testinin yapılması sonucu Pseudomonas aeruginosa tespiti yapılmıștır.

Toplam Koliform ve E.coli tespiti ve sayımı Membran Filtrasyon yöntemi ile TS EN ISO 93081 standartına göre yapıımıștır. Deney numunesi, bakterileri geçirmeyen bir membran filtreyle 
süzülmüș ve bu filtre kromojenik Koliform agar (CCA) üzerine yerleștirilmiștir. Bu membranlar $(36 \pm 2)^{\circ} \mathrm{C}$ de $(21 \pm 3)$ saat inkübe edilmiștir. B-D-galactosidase pozitif koloniler (pembeden kırmızıya) muhtemel Koliform olarak saylırlar. Aeromonas spp gibi oksidaz pozitif bakterilerin neden olduğu yalancı pozitif reaksiyonu ayırmak için, muhtemel koloniler negatif oksidaz (oksidaz testi) reaksiyonu ile doğrulanmıștır. ß-Dgalaktosidaz ve ß-D-glukuronidaz pozitif koloniler (besiyerinde menekșe morundan laciverte kadar olan koloniler) E. coli olarak sayılmıștır. Toplam Koliform sayımı ise E. coli sayısı ile oksidaz negatif olan Koliform bakterilerin toplamı sonucu elde edilmiștir.

Membran Filtrasyon yöntemiyle bağırsak Enterekoklarının tespiti ve sayım yöntemi TS EN ISO 7899-2 standartına göre yapılmıștır. Membran filtre sisteminden $10.45 \mu \mathrm{m}$ ve $47 \mathrm{~mm}$ çapında çizgili steril Membran Filtre Kağıdı) numune suyu süzülerek seçici besiyerine (Slanetz Bartley) yerleștirilmiș ve Petri plağı $(36+2)^{\circ} \mathrm{C}$ de $(44 \pm 4)$ saat inkübe edilmiștir. Tipik olarak koloninin ortasında veya etrafinda, kırmızı, mor veya pembe renk olușumu ile ortaya çıkan tüm koloniler dikkate alınarak safraeskulin-azid agarlı petri ile doğrulama testi yapılmıștır.

Dökme Plak Metoduyla Toplam Canlı tayini TS EN ISO 6222 -02/2002 standartına göre yapılmıștır. $1 \mathrm{ml}$ su örneği dökme plak metoduyla Yeast - Extract seçici besiyerine așılanarak, (22 \pm 1$)$ ${ }^{\circ} \mathrm{C}$ de $(68 \pm 4)$ saat sonunda olușan tüm kolonilerin sayılması sonucu olușan Toplam canlı (Aerobik bakteri, maya ve küf ) sayısı bulunmuștur.

Membran Filtrasyon Metodu ile Clostridium Perfringens (Sporlular dahil) Annex Council Directive 111/98/83/EC standartına göre yapılmıștır. Su numunesi, membran filtrasyon sisteminde $0,22 \mu \mathrm{m}$ filtreden süzülerek (m-CP) agara ekim yapılarak, $44 \pm 1^{\circ} \mathrm{C}^{\prime} \mathrm{de}$ anaerobik ortamda (Anaero jar) $21 \pm 3$ saatlik inkübasyona tabi tutulmuștur. İnkübasyon sonrası petri kabında olușan opak sarı koloniler 20-30 saniye süresince amonyum hidroksit $\left(\mathrm{NH}_{4} \mathrm{OH}\right)$ buharına tutulmuș ve kolonilerden pembe ya da kırmızıya dönenler C. perfringens olarak kabul edilmiștir.

\section{BULGULAR VE TARTIȘMA}

İçilebilir nitelikteki suların mikrobiyal kalitesi sağlık açısından büyük önem tașımaktadır.
Hastalık yapıcı mikroorganizmaların giderilmesi, dezenfeksiyon etkinliğinin değerlendirilmesi açısından ele alınmaktadır.

Suların bakteriyolojik kalitesi, indikatör mikroorganizmalarca belirlenmektedir. Bu amaçla sularda bașta koliform, fekal koliform ve E. coli olmak üzere genel canlı sayısı, Enterokok ve sülfit indirgeyen anaerob'lar aranmaktadır. Bu bakterilerin sudaki varlığı, direkt ya da dolaylı yolla bir fekal bulașmayla birlikte patojenlerin de bulunma olasıllığını ve hijyenik kalitenin yetersizliğini ifade etmektedir (Murcia vd., 2017).

Șekil 2'de seçilen mikroorganizmaların kavitasyon esnasında zamana bağlı olarak gösterdikleri değișim gösterilmektedir. Kavitasyon süresince tüm mikroorganizmaların azaldığı görülmüștür. Kavitasyonun ilk 60. dk'sında giderimin büyük ölçüde sağlandığı görülmüștür. 90. dk'nın sonunda ise tamamen giderim gerçekleșmiștir.

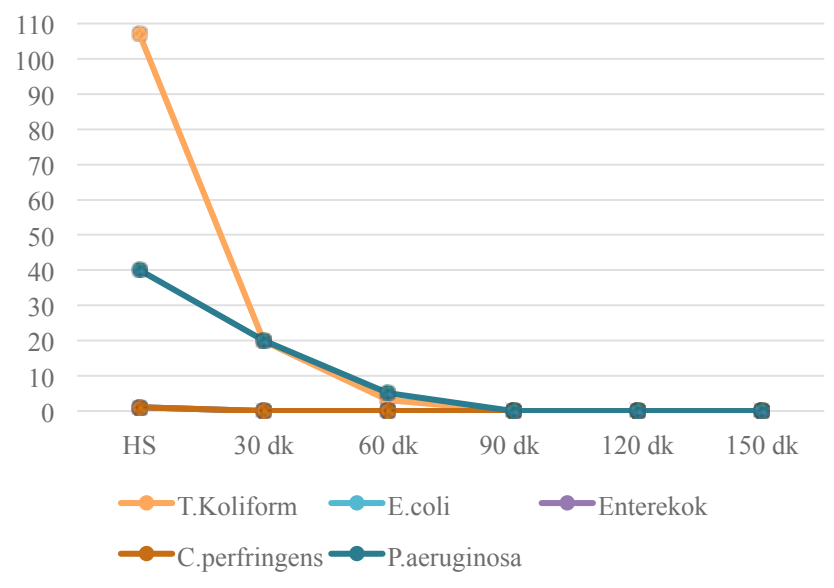

Șekil 2. Kavitasyon süresine bağlı olarak mikroorganizma sayılarının değișimi

Figure 2. Variation of microorganism levels during cavitation time

Enterobacteriaceae familyasında yer alan $E$. coli, insan ve sıcakkanlı hayvanların bağırsak florasında doğal olarak bulunur. Bazı türleri patojen özellik tașır. Patojen olan türler insanlarda gastroenterit ve çeșitli hastalıklara neden olur. E. coli enfeksiyonlarından korunmada hijyen kurallarının uygulanması oldukça önemlidir. Çalıșmada, E. coli ham suda (HS) bașlangıçta 1CFU/100 ml olarak tespit edilmiștir. Kavitasyonun ilk 30.dk'sında E. coli gideriminin tamamen sağlandığı görülmüștür. Mezule vd. (2009) tarafından yapılan laboratuvar ölçekli çalıșmada 
3. dk da \%75 giderim elde edilmiștir. Vitenko ve Gashchyn (2014) tarafından yapılan çalıșmada ise en yüksek dezenfeksiyon oranı $\sigma=0,5$ kavitasyon sayısında 14. dk da \%82 olarak bulunmuștur.

Kavitasyon sayısına göre çalıșma sonuçları değerlendirildiğinde $\sigma=0,31$ kavitasyon sayısında 30. dk sonunda \%100 giderim gerçekleștiği görülmüștür.

Balasundaram ve Harrison (2006) orifis plaka kullanarak intracellular proteinlerin salınmasını sağlayarak E. Coli yıkımını gerçekleștirmișlerdir.

Clostridium perfringens, Bacillaceae familyasına ait Gram pozitif, uçları yuvarlak çubuk șeklinde sporlu, kapsüllü, anaerobik, hareketsiz bir bakteridir. Clostridium perfringens su analizlerinde önemli bir rol oynar. Vejetatif hücrelerle kıyaslandığında ısıya dirençli spor formunda bulunabilmesi, bu organizmaların sulardan tespiti için bir avantaj olarak kullanılır. C.perfringens en önemli sülfit indirgeyen Clostridium cinsi bakteridir ve insan ve hayvan dıșkısında doğal olarak bulunur. Clostridial sporlar sularda koliform bakterilerden, E.coliden ve Enterokoklardan daha uzun yașar ve eski fekal kirliliğin göstergesi olarak kullanılır. Sporlar her zaman klorlamayla da inaktive olmaz. Yüzey suları gibi çevresel sularda, geniș bir dağılıma sahip olan Clostridium türlerinin pek çoğu bulunabilir. Clostridium türlerinin pek çoğu $44^{\circ} \mathrm{C}$ 'de üremezken C.perfringensürer. Bu nedenle $44^{\circ} \mathrm{C}^{\prime}$ de inkübasyon, bazı numunelerde C.perfringens'in izole edilmesi için seçiciliği artırabilir (Berberoğlu, 2012). Sekil 2 incelendiğinde ham suda bașlangıçta 1CFU/100 ml olan sayının ilk 30 dk'da giderildiği görülmektedir.

Pseudomonas aeruginosa sporsuz, polar flagellalı, hareketli, Gram negatif, genellikle kapsülsüz mikroorganizmadır. $P$. aeruginosa genellikle sistemik infeksiyonlara neden olmaktadır. Üriner sistem ile ilgili birçok hastalıktan sorumludur. Bu nedenle sularda bulunması istenemez. P. aeruginosa bașlangıçta 40 CFU/100 $\mathrm{ml}$ olarak tespit edilmiș olup, ilk $60 \mathrm{dk}$ sonunda $\%$ 87,5'lik bir giderim $(0,90$ log'luk) sağlandığı görülmüștür. $90 \mathrm{dk}$ sonunda ise $\% 100$ giderim elde edilmiștir.

Dindar ve Topaç (2018), yaptıkları çalıșmada atıksuyun hidrodinamik kavitasyon sonucunda P. aeruginosa için en belirgin azalmanın 90. dk sonunda \%79'luk bir giderim oranında gerçekleștiğini, kavitasyon sonunda (150.dk) ise yaklașık \%98'lik bir giderim sağlandığı bulmușlardır.
Bağırsak enterokokları Gram-pozitif, genelde zincir formlu, katalaz-negatif ve kokoid-yumurta șekli arasında olabilen ve $D$ antijenine sahip bakterilerdir. Enterokoklar insan ve hayvanların gastrointestinal sisteminde kommensal yașayan, firsatçı patojenlerdir ve idrar yolu enfeksiyonu, endokardit ve sepsise neden olan bakterilerdir (Poulsen vd., 2012; Shafi vd., 2017). Sularda enterokoklar ve stafilokoklar hem fekal hem de organik kontaminasyon indikatörü olarak kullanılmaktadır (Karafistan ve Çolakoğlu,2005). Ham suda 100 ml'de 1 CFU olarak tespit edilen enterokokun ilk $30 \mathrm{dk}$ sonunda giderimi sağlanmıștır.

Toplam koliform bakteri sayısı, su kalitesinin en güvenilir göstergesi olarak kullanılır. Koliform bakteriler insan ve hayvan bağırsağında bulunabileceği gibi çevresel ortamda da bulunabilir ve potansiyel fekal kirliliğin göstergesi olabilirler. Fekal koliformlar ve E.coli ise sadece insan ve hayvan bağırsağında bulunur ve sulardaki varlıkları için yapılan testler, insan ve hayvan orijinli dıșkı kirliliğin doğrulanması için gereklidir (Berberoğlu, 2012). Toplam kolifom sayısı değerlendirildiğinde ham suda 107,1 CFU/100 ml bulunduğu belirlenmiștir. \%82 oranında ciddi bir giderim ilk 30 dk da giderildiği görülmüștür. 60 dk sonunda ise \%97 oranında (1,54 log) giderim gerçekleștiği bulunmuștur.

Șekil 3'de hidrodinamik kavitasyon prosesi boyunca $22^{\circ} \mathrm{C}^{\prime}$ de toplam canlı sayısının değișimi gösterilmektedir. Toplam canlı sayısı, su analizlerinde hijyen indeksi olarak yaygın șekilde kullanılmaktadır. Bu bakterilerin yoğunluğu, suyun hijyenik kalitesi yanı sıra patojenlerin bulunma olasılığını da değerlendirmede yardımcı olmaktadır (Alemdar, 2009).

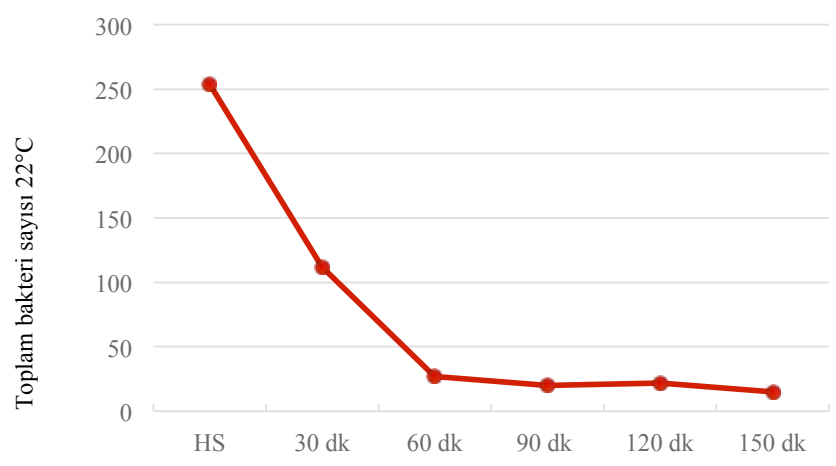

Șekil 3. Kavitasyon süresince toplam bakteri sayısının değișimi

Figure 3. Variation of total bacterial count during cavitation time 
Ham suda toplam canlı sayısı 254 CFU/ml olarak tespitedilmiș olup, kavitasyon süresince azaldığı tespit edilmiștir. İlk $60 \mathrm{dk}$ sonunda toplam canlı sayısında \%89 oranında $(0,90 \mathrm{log})$ ciddi bir azalma meydana geldiği görülmüstür. 90 dk dan sonra toplam canlı sayısında belirgin bir değișim olmadığı gözlenmiștir. Kavitasyonun sonunda ise \%94 oranında (1,23 log) toplam canlı sayısında azalma meydana geldiği tespit edilmiștir. Loraine vd. (2012) yaptığı çalıșmada, atıksuda 45 dakikalık kavitasyon sonrası tüm bakteri miktarında \%80'lik azalıș olduğunu gözlemlemiștir. Hidrodinamik kavitasyonun gram-negative E. coli, Klebsiella pneumoniae, Pseudomonassyringae and Pseudomonas aeruginosa and gram positive Bacillus subtilis türlerinin konsantrayonlarının azalmasında çok etkili olduğunu bulmușlardır.

\section{SONUÇLAR}

Hidrodinamik kavitasyon, bir akıs sisteminde akıș kısıtlaması ile meydana gelen hızlı basınç dalgalanmalarına ve önemli akıșkan kuvvetlerine neden olan bir sistemdir. Bu sayede, hidrodinamik kavitasyon mikrobik hücre hasarına yol açmaktadır. Dolayısıyla, suların dezenfeksiyonu için hidrodinamik kavitasyon etkili bir yöntem olarak kullanılabilmektedir. Bu çalıșma sonucunda 5 bar basıncında ve 0,31 kavitasyon sayısı ile çalıșan bir sistemde ilk 60 dk sonunda etkili bir mikrobiyal giderim sağlandığı görülmüștür. Hidrodinamik kavitasyonda, dezenfeksiyon için herhangi bir kimyasal madde kullanılmadan dezenfeksiyonun sağlanması ekonomik ve çevre dostu bir sistem olarak daha avantajlı bir yöntem olarak değerlendirilmektedir.

İçme ve kullanma sularında insan sağlığı açısından bulunması istenmeyen E.Coli, Toplam Koliform, Enterokok, Clostridium Perfingers, Pseudomonas aeruginosa gibi mikroorganizmaların giderilmesinde etkili olduğu yapılan çalıșma sonucunda ortaya konmuștur.

Son yıllarda su ve atıksu arıtımı konularında etkili ve ekonomik bir yöntem olarak ön plana çıkan hidrodinamik kavitasyon prosesinin, su dezenfeksiyon alanındaki kullanılabilme potansiyelini mikrobiyolojik düzeyde ortaya çıkarması açısından önem tașımaktadır.

\section{TEȘEKKÜR}

Bursa Büyükșehir Belediyesi, BUSKi Genel Müdürlüğü, Dobruca İçme Suyu Arıtma Șube Müdürlüğü'ne katkılarından dolayı teșekkür ederim.

\section{KAYNAKLAR}

Alemdar S, Kahraman T, Ağaoğlu S, Alișarlı M (2009) Bitlis İli İçme Sularının Bazı Mikrobiyolojik ve Fizikokimyasal Özellikleri, Ekoloji 19, 73, 29-38.

Arrojo S, Benito Y, Tarifa AM (2008) A Parametrical Study of Disinfection with Hydrodynamic Cavitation, Ultrasonics Sonochem., 15(5) 903-908.

Balasundaram B, Harrison STL (2006) Study of Physical and Biological Factors Involved in the Disruption of E. coli by Hydrodynamic Cavitation Biotechnol. Prog., 22, 907-913.

Berberoğlu U (2012) Su Mikrobiyolojisi ve Uygulamaları El Kitabı, Türkiye Halk Sağığı Kurumu, Ankara.

Chanda SK (2012) Disitegration of sludge using ozonehydrodynamıc cavitation, Master of Applied Science in the Faculty of Graduate Studies (Civil Engineering), The University of British Columbia, Vancouver.

Council Directive 98/83/EC on the Quality of Water Intended for Human Consumption: Calculation of Derived Activity Concentrations.

Dindar E, Topaç Șağban FO (2018) Uluslararası Su ve Cevre Kongresi, SUCEV2018 Bildiriler Kitabı, 1434-1442, 2224 Mart, Bursa.

Giese N, Darby J (2000) Sensitivity of Microorganisms to Different Wavelengths of UV Light: Implications on Modeling of Medium Pressure UV Systems, Water Res. 34 (16) 40074013.

Gogate PR, Pandit AB (2000) Engineering Design Methods For Cavitation Reactors II: Hydrodynamic Cavitation, AICHE Journal, 46 (8), 1641-1649

Haas CN, Heller B (1990) Kinetics of Inactivation of Giardia Lambia By Free Chlorine, Water Res. 27 (2) 233-238.

Jyoti KK, Pandit AB (2001) Water Disinfection by Acoustic and Hydrodynamic Cavitation, Biochem. Eng. J. 7, 201-212.

Karafistan A, C.olakoğlu FA (2005) Physical, Chemical and Microbiological Water Quality of the Manyas Lake, Turkey. Mitigation and Adaptation Strategies for Global Change. 10, 127- 143.

Labatiuk CW, Belosevic M, Gordon FR (1992) Factors Infuencing The Infectivity Of Giardia Muris Cysts Following Ozone İnactivation in Laboratory and Natural Waters, Water Res. 26 (6) 733- 743.

Li X, et al. (2016).Gas-liquid Mass Transfer Characteristics with Microbubble Aeration - I. Standard stirred tank. Chem Eng Technol., 39(5), 945-952.

Loraine G, Chahine G, Hsiao CT, Choi JK, Aley P (2012) Disinfection of Gram-Negative and Gram-Positive Bacteria

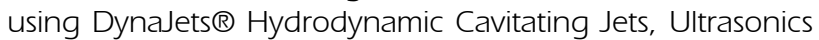
Sonochemistry, 19 (3), 710-717.

Mason TJ, Joyce E, Phull SS, Lorimer JP (2003) Potential Uses of Ultrasound in the Biological Decontamination of Water, Ultrason. Sonochem. 10, 319-323.

Mezule L, et al. (2009). A Simple Technique For Water Disinfection with Hydrodynamic Cavitation: Effect on Survival of Escherichia coli. Desalination; 248 (1-3), 152-9. 
Murcia JJ, Avila-Martinez EG, Rojas H, Navio JA, Hidalgo MC (2017) Study of the E.coli elimination from urban wastewater over photocatalysts based on metallized $\mathrm{TiO} 2$. Applied Catalysis B: Environmental. 200, 469-476.

Poulsen LL, Bisgaard $M$, Son NT, Trung NV, An HM, Dalsgaard A (2012) Enterococcus faecalis Clones in Poultry and in Humans with Urinary Tract Infections, Vietnam. Emerging Infectious Diseases Journal. 18(7), 1096-1 100.

Save SS, Pandit AB, Joshi JB (1994) Use of Hydrodynamic Cavitation For Large Scale Microbial Cell Disruption, Chem. Eng. J. 55, B67.

Shafi S, Kamili AN, Shah MA, Parray JA, Bandh SA (2017). Aquatic Bacterial Diversity: Magnitude, Dynamics, and Controlling, Microbial Pathogenesis, 104, 39-47.

Szulży-Cieplak J, Ozonek J (2013) The Study of the Impact of Select Parameters of Hydrodynamic Cavitation System on Anthracene an Penanthrene Degrardation Rate in Cavitated Liquid Environment) Annual Set the Environment Prorotection 15, 996-1010.
TSENISO 16266 Water quality-Detection and enumeration of Pseudomonas aeruginosa - Method by membrane filtration.

TS EN ISO 6222 Water quality- Enumeration of culturable microorganisms- Colony county by inoculation in a nutient agar culture medium.

TS EN ISO 7899-2 Water quality - Detection and enumeration of intestinal Enterococci - Part 2: Membrane filtration method.

TS EN ISO 9308-1 Water quality- Detection and enumeration of Escherichia coli and coliform bacteria Part-1 Membran filtration method.

Vitenko T, Gashchyn O (2014) Mechanism and Kinetic Regularities of Inactivating Effects of Cavitation on Microorganisms, Chemistry \& Chemical Technology. Vol. 8, № $4,431-440$. 